\title{
Tropospheric column amount of ozone retrieved from SCIAMACHY limb-nadir-matching observations
}

\author{
F. Ebojie ${ }^{1}$, C. von Savigny ${ }^{1, *}$, A. Ladstätter-Weißenmayer ${ }^{1}$, A. Rozanov ${ }^{1}$, M. Weber ${ }^{1}$, K.-U. Eichmann ${ }^{1}$, S. Bötel ${ }^{1}$, \\ N. Rahpoe ${ }^{1}$, H. Bovensmann ${ }^{1}$, and J. P. Burrows ${ }^{1}$ \\ ${ }^{1}$ Institute of Environmental Physics (IUP), University of Bremen, P.O. Box 330440, 28334 Bremen, Germany \\ *now at: Institute of Physics, Ernst-Moritz-Arndt-University of Greifswald, Felix-Hausdorff-Str. 6, \\ 17489 Greifswald, Germany
}

Correspondence to: F. Ebojie (felix@iup.physik.uni-bremen.de)

Received: 31 July 2013 - Published in Atmos. Meas. Tech. Discuss.: 27 August 2013

Revised: 28 May 2014 - Accepted: 6 June 2014 - Published: 10 July 2014

\begin{abstract}
Tropospheric ozone $\left(\mathrm{O}_{3}\right)$, has two main sources: transport from the stratosphere and photochemical production in the troposphere. It plays important roles in atmospheric chemistry and climate change. Its amount and destruction are being modified by anthropogenic activity. Global measurements are needed to test our understanding of its sources and sinks. In this paper, we describe the retrieval of tropospheric $\mathrm{O}_{3}$ columns (TOCs) from the combined limb and nadir observations (hereinafter referred to as limb-nadir-matching (LNM)) of the SCanning Imaging Absorption spectroMeter for Atmospheric CHartographY (SCIAMACHY) instrument, which flew as part of the payload onboard the European Space Agency (ESA) satellite Envisat (2002-2012). The LNM technique used in this study is a residual approach that subtracts stratospheric $\mathrm{O}_{3}$ columns (SOCs), retrieved from the limb observations, from the total $\mathrm{O}_{3}$ columns (TOZs), derived from the nadir observations. The technique requires accurate knowledge of the SOCs, TOZs, tropopause height, and their associated errors. The SOCs were determined from the stratospheric $\mathrm{O}_{3}$ profiles retrieved in the Hartley and Chappuis bands from SCIAMACHY limb scattering measurements. The TOZs were also derived from SCIAMACHY measurements, but in this case from the nadir viewing mode using the Weighting Function Differential Optical Absorption Spectroscopy (WFDOAS) technique in the Huggins band. Comparisons of the TOCs from SCIAMACHY and collocated measurements from ozonesondes in both hemispheres between January 2003 and December 2011 show agreement to within $2-5 \mathrm{DU}\left(1 \mathrm{DU}=2.69 \times 10^{16}\right.$ molecules $\left.\mathrm{cm}^{-2}\right)$. TOC values
\end{abstract}

from SCIAMACHY have also been compared to the results from the Tropospheric Emission Spectrometer (TES) and from the LNM technique exploiting Ozone Monitoring Instrument (OMI) and Microwave Limb Sounder (MLS) data (hereinafter referred to as OMI/MLS). All compared data sets agree within the given data product error range and exhibit similar seasonal variations, which, however, differ in amplitude. The spatial distributions of tropospheric $\mathrm{O}_{3}$ in the SCIAMACHY LNM TOC product show characteristic variations related to stratosphere-troposphere exchange (STE) processes, anthropogenic activities and biospheric emissions.

\section{Introduction}

Ozone is a key species controlling the chemical and radiative balance of the Earth's atmosphere. It is a precursor of hydroxyl radicals $(\mathrm{OH})$, which determine the oxidizing capacity of the lower atmosphere. Thus, tropospheric $\mathrm{O}_{3}$ contributes to the removal of other pollutants from the troposphere. Tropospheric $\mathrm{O}_{3}$ is an important greenhouse gas and air pollutant (e.g. Jacobson, 2012). It is responsible for significant damage to crops and forests, and has adverse effects on the human respiratory system (e.g. Bell et al., 2004; Ebi and McGregor, 2008; Fuhrer and Booker, 2003; Lippmann et al., 1991).

One major challenge in the retrieval of tropospheric $\mathrm{O}_{3}$ from space observations is that it requires accurate knowledge of stratospheric $\mathrm{O}_{3}$, which accounts on average for $\sim 90 \%$ of the total $\mathrm{O}_{3}$ columns (TOZs). In addition, $\mathrm{O}_{3}$ is 
highly variable, as a result of the changes in its chemistry (i.e. sources, reactions and sinks) and dynamics. For example, diurnal variation of $\mathrm{O}_{3}$ in the boundary layer can be significant. However, Stevenson et al. (2006) have estimated a mean lifetime of $\mathrm{O}_{3}$ in the free troposphere of about 22 days. In general, spatial and temporal sampling of parameters must be finer than the spatial and temporal scale of the physi$\mathrm{cal} / \mathrm{chemical}$ phenomenon being investigated. Nyquist sampling theory indicates that significant changes from scales of twice the temporal and/or spatial sampling can be retrieved in principle. The sampling of tropospheric $\mathrm{O}_{3}$ by the SCIAMACHY instrument, which reaches global coverage in the tropics within 6 days, results in significance being achieved conservatively at the monthly mean scale.

A number of methods for retrieving tropospheric $\mathrm{O}_{3}$ from satellite observations have been proposed. The retrieval of tropospheric $\mathrm{O}_{3}$ from satellite instruments using the residual approach started in the late 1980s (Fishman and Larsen, 1987). In this method the tropospheric $\mathrm{O}_{3}$ columns (TOCs) were obtained by subtracting the stratospheric $\mathrm{O}_{3}$ columns (SOCs) retrieved from SAGE (Stratospheric Aerosol and Gas Experiment) measurements from the TOZs derived from TOMS (Total Ozone Mapping Spectrometer) observations. Several other residual-based approaches have been developed over the years (e.g. Fishman et al., 1990; Fishman and Balok, 1999; Ladstätter-Weißenmayer et al., 2004; Thompson and Hudson, 1999; Ziemke et al., 1998, 2006; Schoeberl et al., 2007; Ziemke et al., 2011). Also, Kim et al. (2001) have used the scan angle geometry technique to retrieve tropical tropospheric $\mathrm{O}_{3}$, a method that requires multi-angle measurements.

A retrieval of tropospheric $\mathrm{O}_{3}$ from near-simultaneous nadir measurements in the Hartley and Huggins bands of $\mathrm{O}_{3}$ has been shown to be feasible. This approach exploits the different penetration depths at different wavelengths to obtain information on the vertical distribution of $\mathrm{O}_{3}$. It was first described by Singer and Wentworth (1957) and then used by Bhartia et al. (1996, 2013), Munro et al. (1998), Hoogen et al. $(1998,1999)$ and Liu et al. $(2006,2010)$ among others to retrieve $\mathrm{O}_{3}$ profiles at a moderate to low vertical resolution. This method, however, requires very accurate measurements between 250 and $350 \mathrm{~nm}$ of the upwelling radiation at the top of atmosphere, which changes in this range by several orders of magnitude. As shown by theoretical studies (Natraj et al., 2011), additional information on the vertical distribution of ozone in the lower atmosphere is obtained by combining measurements in the visible and UV spectral range. This, however, makes the retrieval more sensitive to the spectral characteristics of the surface reflection and weaker absorption features like chlorophyll and liquid water (e.g. Vountas et al., 2007).

Tropospheric $\mathrm{O}_{3}$ has also been retrieved from nadir measurements of thermal infrared (TIR) emission (Aumann et al., 2003; Beer, 2006). However, as the signal in the thermal infrared depends on the thermal contrast, sensitivity is poor in the lower troposphere and maximizes in the upper troposphere and lower stratosphere.

Another approach to retrieve tropospheric $\mathrm{O}_{3}$ is the use of simultaneous observations in the UV, visible and TIR spectral ranges, as first proposed in the GeoTROPE studies (Burrows et al., 2004). The TIR $\mathrm{O}_{3}$ signal is dependent on the temperature and $\mathrm{O}_{3}$ profiles. The capabilities of this technique have been demonstrated by synthetic retrievals in $\mathrm{Na}-$ traj et al. (2011) and Worden et al. (2007). A similar technique has also been applied to retrieve tropospheric $\mathrm{O}_{3}$ using infrared radiance spectra recorded by the Infrared Atmospheric Sounding Interferometer (IASI) and GOME-2 ultraviolet measurements (Cuesta et al., 2013).

Tropospheric $\mathrm{O}_{3}$ amounts have also been determined using neural network (NN) algorithms (e.g. Müller et al., 2003; Sellitto et al., 2011; Di Noia et al., 2013). The NN approach combines reflectances obtained in satellite nadir viewing measurements with temperature and tropopause pressure information to yield global estimates of TOC.

In this study, we focus on the limb-nadir-matching (LNM) technique applied to SCIAMACHY limb and nadir measurements. The retrieval of tropospheric amounts of such species as $\mathrm{O}_{3}$ by using the LNM technique was one of the principal objectives of the SCIAMACHY instrument (Burrows et al., 1995; Bovensmann et al., 1999; Gottwald and Bovensmann, 2011). Tropospheric amounts of species are obtained by subtracting their stratospheric amounts, which are retrieved from the limb viewing measurements, from the total amounts obtained from the nadir observations performed by the same instrument. This approach is similar in concept to that developed in the late 1980s (Fishman and Larsen, 1987; Fishman et al., 1990). One unique aspect of the retrieval is that the total column (nadir) and stratospheric profile (limb) data from the same instrument are used. This reduces some of the uncertainties due to instrumental issues and SCIAMACHY provides a dense sampling of tropospheric $\mathrm{O}_{3}$ on a global scale.

The retrieval of atmospheric trace gases using the residual approach through the combination of limb and nadir measurements from SCIAMACHY has been previously applied to $\mathrm{O}_{3}$ and $\mathrm{NO}_{2}$ (Sierk et al., 2006; Sioris et al., 2004; Beirle et al., 2010; Hilboll, 2013). The global retrieval of tropospheric $\mathrm{O}_{3}$ from SCIAMACHY using the LNM technique is advantageous, because it does not require any further assumptions, such as zonal homogeneity of stratospheric $\mathrm{O}_{3}$ or an estimate from model data. The algorithm extracts tropospheric $\mathrm{O}_{3}$ information from observations of nearly the same air mass, probed in both nadir and limb geometry.

This paper presents the tropospheric $\mathrm{O}_{3}$ data set from SCIAMACHY and an error analysis. These data are important to assess our understanding of the processes controlling tropospheric $\mathrm{O}_{3}$ abundances and to evaluate chemical transport and chemistry climate models during the decade 20022012. The paper describes a first evaluation of the TOC from SCIAMACHY by comparisons with TOC from ozonesondes 
as well as TOC data sets from other satellite instruments. The paper is organized as follows: Sect. 2 briefly describes the SCIAMACHY instrument on Envisat and other instruments relevant to this study; Sect. 3 summarizes the retrieval method used; Sect. 4 presents a sensitivity study, estimating both systematic and random errors from all relevant error sources. Section 5, which compares SCIAMACHY, Tropospheric Emission Spectrometer (TES), Ozone Monitoring Instrument and Microwave Limb Sounder (OMI/MLS), and ozonesonde observations, provides evaluation results of the TOCs, retrieved from the SCIAMACHY LNM technique, and Sect. 6 summarizes our principal findings and conclusions.

\section{Instrument description}

\subsection{SCIAMACHY}

SCIAMACHY (Burrows et al., 1995; Bovensmann et al., 1999), was a passive spectrometer, and part of the payload of ESA's Environmental Satellite (Envisat) launched on 28 February 2002. Unfortunately, on 8 April 2012 contact with Envisat was lost and thus far, ESA has failed to re-establish contact. Envisat orbited the earth in a sunsynchronous, near-polar orbit at a mean altitude of typically about $800 \mathrm{~km}$, but was lowered by $17 \mathrm{~km}$ in late 2010 . It had an inclination relative to the equatorial plane of $98.5^{\circ}$ with an orbital period of about $100 \mathrm{~min}$, thus completing about 14.3 orbits a day (Gottwald and Bovensmann, 2011). Its local equator crossing time was 10:00 a.m. in descending node. SCIAMACHY measured the transmitted, reflected and scattered solar radiation in the UV, visible, and near-infrared (NIR) wavelength regions (214-2386 nm) with a spectral resolution varying between $0.22 \mathrm{~nm}$ and $1.48 \mathrm{~nm}$. The observations were contiguous from $214 \mathrm{~nm}$ to $1750 \mathrm{~nm}$ with two additional channels: $1940-2040 \mathrm{~nm}$ and $2265-2380 \mathrm{~nm}$. The scan mirror system enabled three different viewing geometries: nadir, limb and solar/lunar occultation.

In the nadir mode, the SCIAMACHY instrument scanned the region underneath the spacecraft, thus detecting upwelling solar radiation that has been scattered in the atmosphere and reflected by the Earth's surface. The nadir pointing mirror scanned across the satellite track and each full scan covered a ground area of approximately $30 \mathrm{~km}$ along track by $960 \mathrm{~km}$ across track with the footprint of a single observation being typically $30 \mathrm{~km} \times 60 \mathrm{~km}$.

In the limb mode, the instrument line of sight was directed tangentially to the Earth's surface as the instrument scanned in the horizontal and vertical direction with elevation steps of approximately $3.3 \mathrm{~km}$ at the tangent point (Gottwald and Bovensmann, 2011). The tangent height was raised in discrete steps from the surface up to about $100 \mathrm{~km}$, thus providing vertically resolved information on the atmospheric state. The instantaneous field of view at the tangent point was about $110 \mathrm{~km}$ (horizontally) $\times \sim 2.6 \mathrm{~km}$ (vertically). For every limb state, a horizontal scan with a cross-track coverage of $960 \mathrm{~km}$ and typically four readouts were performed. This resulted in a typical horizontal resolution of $240 \mathrm{~km}$. The limb and nadir measurements used in this study were only performed in the sunlit part of the Earth.

A special feature of SCIAMACHY was the matched limbnadir measurement (LNM) mode as illustrated by Fig. 1, which enabled the instrument to observe the same atmospheric volume, first in limb and then after about $7 \mathrm{~min}$ in nadir viewing geometry. Originally, two SCIAMACHY instruments were proposed measuring in nadir and limb simultaneously. As only one instrument was funded, this LNM mode of observation was introduced to facilitate the separation of the tropospheric abundance of absorbing constituents from that in the middle atmosphere. SCIAMACHY achieved the global coverage in approximately 6 days with the least dense sampling at the equator (Bovensmann et al., 1999).

\subsection{TES, OMI and MLS}

TES, OMI and MLS are satellite instruments aboard the Aura spacecraft, which was launched into a sun-synchronous polar orbit in July 2004 at an inclination angle of $98.2^{\circ}$ and an altitude of about $705 \mathrm{~km}$. The spacecraft has an equatorial crossing time of approximately 01:45 p.m. in ascending node and takes about $98.8 \mathrm{~min}$ to cover an orbit, thereby completing about 14.6 orbits per day.

TES is a Fourier transform IR spectrometer covering the spectral range of $650-3050 \mathrm{~cm}^{-1}(3.3-15.4 \mu \mathrm{m})$ at a spectral resolution of $0.1 \mathrm{~cm}^{-1}$ in the nadir viewing mode (Beer, 2006). The nadir vertical profiles are $1.6^{\circ}$ apart along the orbital track with a footprint of about $5 \mathrm{~km} \times 8 \mathrm{~km}$ (Beer et al., 2001). TES covers the globe in 16 days in the crosstrack mode. For our analysis we used TES V003 monthly mean tropospheric $\mathrm{O}_{3}$ data downloaded from http://eosweb. larc.nasa.gov/, which were retrieved using the optimal estimation (OE) technique (Rodgers, 2000) as described in detail by Bowman et al. (2006).

TES measurements provide $\mathrm{O}_{3}$ profiles with a vertical resolution of approximately $6 \mathrm{~km}$, corresponding to about $1-$ 2 degrees of freedom (DOFs) in the troposphere, using NCEP (National Centers for Environmental Prediction) tropopause height data. Tropical and subtropical clear-sky measurements provide the highest number of DOFs, when the TES retrieval is best able to distinguish between lower and upper tropospheric $\mathrm{O}_{3}$ (Jourdain et al., 2007). The ozone a priori profiles are derived from the Model of Ozone and Related Tracers (MOZART) CTM (Brasseur et al., 1998) monthly means, which are averaged in $10^{\circ}$ latitude $\times 60^{\circ}$ longitude grid boxes (Bowman et al., 2006). Although the limited vertical resolution of the TES profile retrievals can lead to a bias when comparing with other data products, the TOC values are reasonable (Tang and Prather, 2012). A description of 


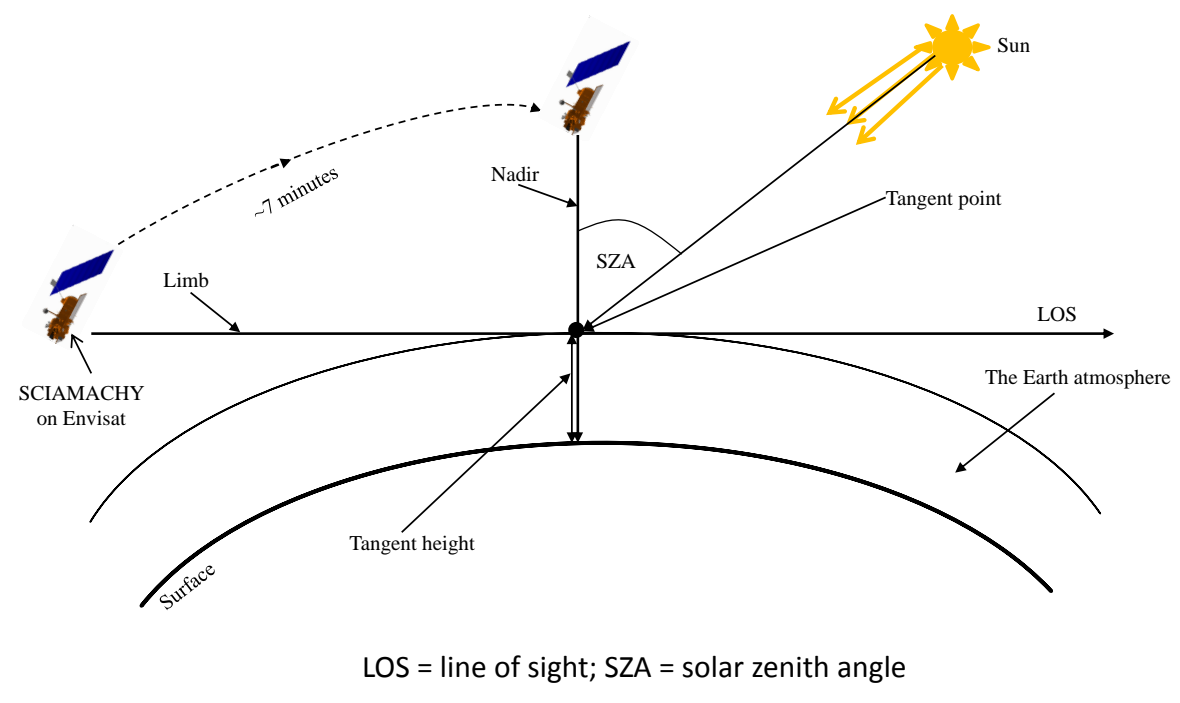

Figure 1. Illustration of SCIAMACHY limb and nadir observation geometries.

TES data product used in this study is given by Osterman et al. (2006).

TES tropospheric $\mathrm{O}_{3}$ data were screened using the $\mathrm{O}_{3}$ data quality flag (Osterman et al., 2006), the emission layer flag (Nassar et al., 2008), and cloud top pressures and cloud effective optical depth (Kulawik et al., 2006; Eldering et al., 2008). Validation studies showed that TES tropospheric $\mathrm{O}_{3}$ overestimates the reference data with an average bias of 311 ppbv (e.g. Boxe et al., 2010). It has been reported that TES $\mathrm{O}_{3}$ profiles are biased high throughout the troposphere by up to $15 \%$ (Nassar et al., 2008). Comparisons of TES TOCs with ozonesondes, shown in Fig. 3 of Nassar et al. (2008), reveal that TES TOCs are high biased by $2.6 \mathrm{DU}$ in the tropics, 5.1 DU in the northern subtropics, 3.3 DU in the northern midlatitudes and about 1.9 DU in the southern low and midlatitudes (Nassar et al., 2008).

OMI is a UV-visible nadir viewing spectrometer detecting backscattered solar radiation over the $270-500 \mathrm{~nm}$ wavelength range with a spectral resolution of $0.42-0.63 \mathrm{~nm}$ (Levelt et al., 2006). It has a spatial resolution of $13 \mathrm{~km} \times 24 \mathrm{~km}$ and covers the globe in 1 day, thus providing daily information on the TOZs. TOZs from OMI are obtained using the OMI-TOMS retrieval algorithms version 8 described in http://ozoneaq.gsfc.nasa.gov/doc/ATBD-OMI-04.pdf. For determining tropospheric $\mathrm{O}_{3}$ in combination with MLS data, the TOZs from OMI have been screened as follows. Scenes with solar zenith angle (SZA) greater than $84^{\circ}$ are screened out (Ziemke et al., 2006). Also surface glint, $\mathrm{SO}_{2}$ contamination and some other factors are flagged (Ziemke et al., 2006). Furthermore, cloudy scenes are screened by rejecting $\mathrm{O}_{3}$ measurements with reflectivity greater than 0.3 (Ziemke et al., 2006). This data product has been extensively validated with both ground-based and satellite instruments. Comparisons between the TOZ values from OMI and
Dobson spectrometers show an agreement to within $1 \%$ in the global mean (Balis et al., 2007).

The MLS instrument is a thermal-emission microwave limb sounder that yields vertical profiles of $\mathrm{O}_{3}$, providing information on the SOC. The spatial resolution of MLS is about $5 \mathrm{~km}$ cross-track $\times 500 \mathrm{~km}$ along-track $\times 3 \mathrm{~km}$ vertically, depending on the parameter under observation (Waters et al., 2006). Details of the instrument description and measurement techniques are discussed by Waters et al. (2006). An analysis of SOCs derived from MLS version 3.3 and an earlier version 2.2 (Froidevaux et al., 2006, 2008), show a systematic offset of about +2.5 DU (Ziemke et al., 2011). It has also been documented that a low bias in the OMI/MLS tropospheric $\mathrm{O}_{3}$ is probably due to $\mathrm{MLS} \mathrm{O}_{3}$ being high biased in the lowermost stratosphere (Livesey et al., 2011).

The MLS measurements are made about 7 min before OMI views the same location during ascending (daytime) orbital tracks. To determine the TOC and the SOC, tropopause pressure determined from NCEP analysis based on the $2 \mathrm{~K} \mathrm{~km}^{-1}$ thermal tropopause criterion of the World Meteorological Organization (WMO, 1957) is used. The TOCs are derived by subtracting the vertically integrated $\mathrm{MLS} \mathrm{O}_{3}$ profiles from the OMI TOZ. For our analysis we used OMI/MLS TOC, described in detail by Ziemke et al. (2006). This data product has been validated by comparison with ozonesondes. The results indicated an agreement to within a few DU.

\subsection{Ozonesondes}

Ozonesondes provide in situ measurements of $\mathrm{O}_{3}$ vertical profiles, ambient air temperature, pressure and humidity up to an altitude typically of around $30-35 \mathrm{~km}$ with a vertical resolution of about $150 \mathrm{~m}$. The ozonesonde data set used in our analysis is obtained with the electrochemical 
concentration cell (ECC) (Komhyr, 1969), Brewer-Mast (BM) (Brewer and Milford, 1960), and the carbon iodine cell (KC96) (Kobayashi and Toyama, 1966) detectors. The data sets are available at http://www.woudc. org/ (WOUDC, 2007) and http://croc.gsfc.nasa.gov/shadoz/ (Thompson et al., 2003). We first determined the tropopause heights from the temperature profile measurements by using the thermal tropopause definition (WMO, 1957), and then the TOCs were estimated by integrating the $\mathrm{O}_{3}$ concentration $\left(c_{i}\right)$ from the surface to the tropopause as follows:

$$
\text { TOC }=\frac{1}{2} \sum_{i=1}^{i_{\max }-1}\left[\left(c_{i+1}+c_{i}\right)\left(h_{i+1}-h_{i}\right)\right],
$$

where $c_{i}$ is given by

$c_{i}=\frac{N_{\mathrm{A}} P_{i}}{R T_{i}}$,

where $i$ represents the level index, $h$ is the height, $N_{\mathrm{A}}$ is Avogadro's number, $R$ is the ideal gas constant, and $T$ and $P$ are the temperature and $\mathrm{O}_{3}$ partial pressure, respectively.

A study by Stübi et al. (2008) shows that the tropospheric $\mathrm{O}_{3}$ values derived from ECC and BM sondes agree to within $5 \%$. An analysis of MOZAIC (Measurement of Ozone and Water Vapour by Airbus In-Service Aircraft) time series and sonde data over Frankfurt and Munich (1999-2008) show mean biases of $0.9 \pm 2.8 \mathrm{ppbv}$ at one sigma in the lower troposphere (681-580 hpa) and $1.7 \pm 3.8 \mathrm{ppbv}$ in the upper troposphere (501-430 hpa) (Logan et al., 2012). Irrespective of the sensor type, ozonesonde data are of sufficient quality (WOUDC, 2007) to be used to validate SCIAMACHY tropospheric $\mathrm{O}_{3}$.

\section{Method and data analysis from SCIAMACHY}

\subsection{Stratospheric ozone profile retrievals from SCIAMACHY limb measurements}

Stratospheric $\mathrm{O}_{3}$ profiles were retrieved from SCIAMACHY limb-viewing measurements. The retrieval version 2.9 , used in this analysis, is an update of version 2.1, described in Sonkaew et al. (2009). This retrieval algorithm includes in the forward radiative transfer calculations the surface albedo database by Matthews (1984) and the empirical aerosol extinction profile model ECSTRA developed by Fussen and Bingen (1999). Briefly, the retrieval of stratospheric $\mathrm{O}_{3}$ profiles, utilizes the combination of three wavelengths $(525,589$ and $675 \mathrm{~nm}$ ) in the $\mathrm{O}_{3}$ Chappuis band (Flittner et al., 2000; von Savigny et al., 2003) and several wavelengths in the UV Hartley-Huggins bands (264, 267.5, 273.5, 283, 286, 288, 290 and $305 \mathrm{~nm}$ ) to cover the altitude range from 10 to $80 \mathrm{~km}$. Independent of the latitude, the retrieved $\mathrm{O}_{3}$ profile is determined mostly by UV absorption above $40 \mathrm{~km}$ and by visible absorption below $35 \mathrm{~km}$, while both spectral channels contribute in the transition region. In the selection of the wavelengths in the Hartley-Huggins bands, care is taken to avoid contamination of the limb scattering measurements by airglow emissions and strong Fraunhofer lines (Rohen, 2006).

The retrieval is done by using a non-linear inversion scheme with the first-order Tikhonov regularization. The forward simulations are performed with the SCIATRAN radiative transfer model (RTM) (Rozanov et al., 2014). Errors arise potentially from uncertainties in the knowledge of clouds, tangent height registration, effective albedo and aerosol extinction. External stray light, which is a contamination from radiation coming from outside the field of view of the instrument, e.g. from clouds and the earth brightness, is another source of error. To reduce the effect of clouds and albedo on the retrieval, the radiance profiles are normalized by the limb radiance at a wavelength-dependent reference tangent height. Comparison of the SCIAMACHY stratospheric $\mathrm{O}_{3}$ data product with the results from MLS, SABER, SAGE II and ACE-FTS show an agreement of typically better than $10 \%$ globally, although larger biases exist around $30 \mathrm{~km}$ in the tropics and below $20 \mathrm{~km}$ at all latitudes (Mieruch et al., 2012).

\subsection{Total ozone column retrievals from SCIAMACHY nadir measurements}

The Weighting Function Differential Optical Absorption Spectroscopy (WFDOAS) algorithm (Coldewey-Egbers et al., 2005; Weber et al., 2005) is used to retrieve TOZs from the SCIAMACHY nadir-viewing measurements. In contrast to the standard DOAS technique, which uses the $\mathrm{O}_{3}$ cross section in the fit procedure, the WFDOAS algorithm exploits the weighting function for the retrieval of TOZ. The latter is obtained by a vertical integration of the altitude-dependent weighting function of $\mathrm{O}_{3}$. The fitting window from $326.6 \mathrm{~nm}$ to $334.5 \mathrm{~nm}$ is used for the TOZ retrieval. The WFDOAS technique accounts for the effect of rotational Raman scattering (Ring effect) by using a simple approximation (Weber et al., 2007). Our investigations show that despite a decreased sensitivity, clear-sky nadir measurements still contain information on boundary layer ozone amount. WFDOAS total $\mathrm{O}_{3}$ from GOME and SCIAMACHY is mature and agrees with TOZs from ground-based and balloon-borne instruments typically within $1 \%$ (e.g. Bracher et al., 2005; Weber et al., $2005,2013)$. In the polar regions, and at high SZAs, biases can be larger (Weber et al., 2005).

\subsection{Combination of SCIAMACHY limb and nadir measurements}

The overarching objective of the LNM retrievals from SCIAMACHY is an accurate determination of the tropospheric amount of trace species, which have significant stratospheric absorption. The SCIAMACHY instrument was designed to alternate between the limb and nadir observations so that the region probed during the limb scan can be observed about $7 \mathrm{~min}$ before the nadir scan. The limb measurements yield, 


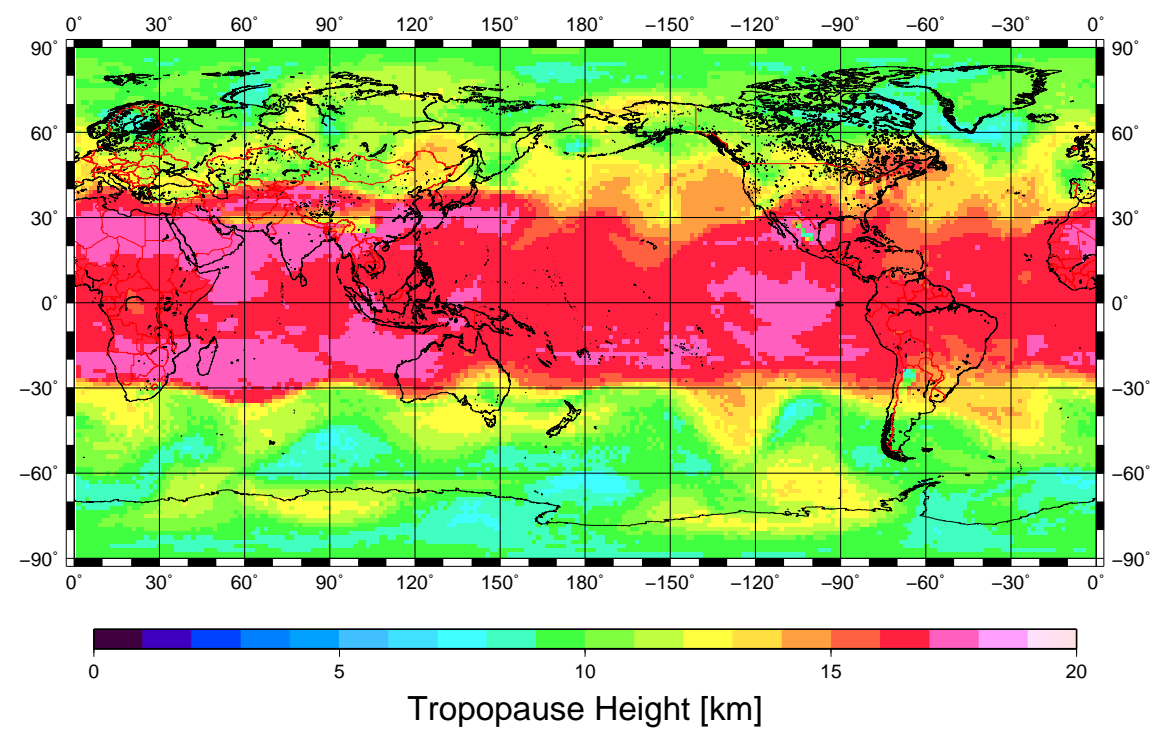

Figure 2. Distribution of global tropopause height on 28 June 2005 derived from the ECMWF ERA-Interim re-analysis.

to a first approximation, the stratospheric vertical profiles of trace gases above the region of the nadir mode measurements of total columns. Integrating the coincident stratospheric profiles from the tropopause upwards provides the stratospheric vertical column density above the target area. The subtraction of the stratospheric column amount from the total column measured in nadir yields the tropospheric column amounts.

To determine the stratospheric ozone column, the tropopause height needs to be determined. We computed the tropopause heights from the European Centre for Medium Range Weather Forecasts (ECMWF) reanalyses (ERA)-Interim data. These data comprise three-dimensional fields of pressure, temperature and wind vectors on a latitude/longitude grid of $1.5^{\circ} \times 1.5^{\circ}$ with 91 altitude levels and four analysis times daily. The location of the tropopause is obtained by applying the dynamical (potential vorticity, PV) and the thermal (lapse rate) definitions of the tropopause. The thermal tropopause is defined as the lowest level at which the lapse rate is $2 \mathrm{~K} \mathrm{~km}^{-1}$ or less, provided also that the average lapse rate between this level and all higher levels within $2 \mathrm{~km}$ does not exceed $2 \mathrm{~K} \mathrm{~km}^{-1}$ (WMO, 1957). The definition of the dynamic tropopause is based upon stability criteria. The stratospheric air masses are characterized by high PVs while the tropospheric air masses have low PVs. Thus, there is a sharp gradient of PV between these two air masses. The dynamical tropopause is located within a transition layer between the tropospheric and stratospheric air masses, which is characterized by the PV values of 24 PVU (e.g. Holton et al., 1995; Wernli and Bourqui, 2002) (1 PVU equals $1.0 \times 10^{-6} \mathrm{~m}^{2} \mathrm{~s}^{-1} \mathrm{~K} \mathrm{~kg}^{-1}$ ). In our analysis, we used 3.0 PVU and higher to define stratospheric air. To determine the tropopause height using both criteria we followed an approach similar to that discussed in Hoinka
(1998). For the tropics (i.e. $\pm 20^{\circ}$ latitude from the equator) we applied the thermal criterion and from the midlatitudes to the poles (latitudes higher than $30^{\circ}$ in both hemispheres) we applied the dynamical criterion. In the transition region between the two regimes $\left(20-30^{\circ}\right.$ in both hemispheres), both criteria were used and weighted with the distance from the regime boundaries. The ECMWF analysis data were interpolated in latitude and longitude while the time closest to the SCIAMACHY observation was used. An example of the global distribution of the derived tropopause heights for 28 June 2005 is shown in Fig. 2. Comparisons of the tropopause heights computed from ozonesonde temperature profile measurements and ECMWF data sets show good agreement with a mean difference of less than $500 \mathrm{~m}$ in both hemispheres for the stations considered in this study.

The SOCs from SCIAMACHY were derived by integrating $\mathrm{O}_{3}$ profiles from the tropopause height to about $80 \mathrm{~km}$ as follows (Eq. 3):

$\mathrm{SOC}=\sum_{i_{\mathrm{tph}}}^{i=79}\left(\frac{N\left(z_{i+1}\right)+N\left(z_{i}\right)}{2}\right)\left(z_{i}-z_{i+1}\right)$,

where $N_{(z)}$ is the stratospheric $\mathrm{O}_{3}$ profile in number density at a fixed altitude grid of $1 \mathrm{~km}, z$ is the altitude and $i$ is the index.

At higher latitudes, where the tropopause is below $10 \mathrm{~km}$, the stratospheric $\mathrm{O}_{3}$ profiles below the lowest retrieval altitude were constructed from ozonesonde climatological profiles (2003-2011) scaled to match the lower part of the retrieved SCIAMACHY profile, which is $\sim 10 \mathrm{~km}$. The ground area covered by a single limb measurement is about $400 \mathrm{~km}$ (along track) $\times 240 \mathrm{~km}$ (across track) and that of an individual nadir state is approximately $30 \mathrm{~km}$ (across track) $\times 60 \mathrm{~km}$ (along track). In order to determine the TOC, the subsequent 
Table 1. Monthly average and errors in TOCs, SOCs, TOZs, and the effect of the tropopause height error determined in 2006. The error in the monthly mean represents one standard deviation.

\begin{tabular}{|c|c|c|c|c|c|c|c|c|c|c|c|c|}
\hline \multirow[t]{2}{*}{ Month } & \multirow{2}{*}{$\begin{array}{l}\text { Mean } \\
\text { TOC } \\
\\
\text { DU }\end{array}$} & \multicolumn{2}{|c|}{$\begin{array}{l}\text { Resulting } \\
\text { error in TOC }\end{array}$} & \multirow{2}{*}{$\begin{array}{l}\text { Mean SOC } \\
\text { DU }\end{array}$} & \multicolumn{2}{|c|}{ Error of SOC } & \multirow{2}{*}{$\begin{array}{l}\text { Mean TOZ } \\
\text { DU }\end{array}$} & \multicolumn{2}{|c|}{ Error of TOZ } & \multirow{2}{*}{$\begin{array}{l}\text { Mean } \\
\text { tropopause } \\
\text { height } \\
\mathrm{km}\end{array}$} & \multicolumn{2}{|c|}{$\begin{array}{l}\text { Ozone error } \\
\text { caused by } \\
\text { tropopause } \\
\text { height error }\end{array}$} \\
\hline & & DU & $\%$ & & DU & $\%$ & & DU & $\%$ & & DU & $\%$ \\
\hline 200601 & 30.1 & 6.7 & 22.4 & 251.4 & 6.1 & 2.5 & 282.7 & 2.8 & 1.0 & 12.9 & 0.2 & 0.5 \\
\hline 200602 & 27.7 & 7.1 & 25.7 & 260.7 & 6.5 & 2.5 & 290.7 & 2.9 & 1.0 & 12.4 & 0.2 & 0.6 \\
\hline 200603 & 30.1 & 8.0 & 26.4 & 275.0 & 7.3 & 2.6 & 307.5 & 3.1 & 1.0 & 12.0 & 0.2 & 0.6 \\
\hline 200604 & 29.0 & 7.9 & 27.1 & 276.3 & 7.2 & 2.6 & 307.8 & 3.1 & 1.0 & 12.0 & 0.2 & 0.5 \\
\hline 200605 & 29.3 & 7.3 & 25.0 & 268.1 & 6.7 & 2.5 & 299.9 & 3.0 & 1.0 & 12.2 & 0.1 & 0.4 \\
\hline 200606 & 28.7 & 7.1 & 24.9 & 264.7 & 6.5 & 2.5 & 295.9 & 3.0 & 1.0 & 12.1 & 0.1 & 0.4 \\
\hline 200607 & 28.0 & 6.9 & 24.7 & 260.6 & 6.3 & 2.4 & 291.2 & 2.9 & 1.0 & 12.2 & 0.1 & 0.4 \\
\hline 200608 & 28.8 & 6.9 & 24.0 & 260.8 & 6.3 & 2.4 & 292.0 & 2.9 & 1.0 & 12.1 & 0.1 & 0.4 \\
\hline 200609 & 30.0 & 6.9 & 23.1 & 259.9 & 6.3 & 2.5 & 292.4 & 2.9 & 1.0 & 11.9 & 0.1 & 0.3 \\
\hline 200610 & 32.4 & 7.0 & 21.5 & 259.2 & 6.3 & 2.5 & 294.5 & 2.9 & 1.0 & 11.9 & 0.1 & 0.3 \\
\hline 200611 & 33.8 & 7.0 & 20.7 & 255.1 & 6.4 & 2.5 & 291.8 & 2.9 & 1.0 & 11.8 & 0.1 & 0.3 \\
\hline 200612 & 33.1 & 7.0 & 21.1 & 253.3 & 6.4 & 2.6 & 289.2 & 2.9 & 1.0 & 11.7 & 0.1 & 0.3 \\
\hline
\end{tabular}

nadir measurements that matched with the limb measurement are averaged such that the ground area corresponding to a single tropospheric column value is about $60 \mathrm{~km} \times 240 \mathrm{~km}$. The TOC is obtained by subtracting SOC from TOZ.

One of the factors that affect the atmospheric radiative transfer at wavelengths important for tropospheric ozone retrieval is clouds. Clouds play an important role in reflection, absorption and transmission of solar radiation, thus affecting trace gas retrievals. In the nadir measurements for example, clouds have three major effects on the $\mathrm{O}_{3}$ retrievals. These are the albedo effect, an increase of the in-cloud absorption, and a shielding effect (Koelemeijer and Stammes, 1999; Newchurch et al., 2001).

In the TOZ retrievals using the WFDOAS technique, clouds are treated as Lambertian reflecting surfaces (Coldewey-Egbers et al., 2005). Cloud top height and cloud fraction from SACURA as applied to SCIAMACHY (Kokhanovsky and Rozanov, 2004) are used to determine an effective bottom of atmosphere (BOA) height. For a clearsky scene, this becomes the surface height. For a fully cloudy scene the cloud top height is the BOA. The effective albedo of the BOA is determined using the Lambertian equivalent reflectivity (LER) at $377 \mathrm{~nm}$. The missing $\mathrm{O}_{3}$ below the cloud is corrected for by adding to the retrieved $\mathrm{O}_{3}$ column the socalled ghost vertical column, which is derived from an $\mathrm{O}_{3}$ profile climatology. In cases of very high clouds, the tropospheric contribution to the total column is then solely determined by climatological $\mathrm{O}_{3}$. For this reason, we only use total $\mathrm{O}_{3}$ data for scenes having cloud fractions of less than or equal to $10 \%$ when deriving the TOC.

Clouds are also detected in the limb viewing mode using the SCIAMACHY cloud detection algorithm (SCODA) (Eichmann et al., 2009). SCODA uses vertical profiles of colour index ratios, calculated from different wavelength pairs, to determine the cloud top height and cloud thermodynamic phase (ice, liquid). Since TOCs constitute only about $10 \%$ of the TOZs, small errors associated with clouds might significantly affect the derived TOCs. Therefore, limb scenes that are contaminated with clouds and nadir measurements that have a cloud fraction of more than 0.1 were screened out. A sensitivity analysis showed that an increase in nadir cloud fraction threshold by $10 \%$ can on average reduce SCIAMACHY tropospheric $\mathrm{O}_{3}$ by about $1 \mathrm{DU}$. This is mostly observed in cases where pollution increases tropospheric $\mathrm{O}_{3}$ to values above the climatological $\mathrm{O}_{3}$.

Furthermore, to minimize uncertainties in the retrieved tropospheric $\mathrm{O}_{3}$, we restrict the analysis to measurements from the descending part of the orbit with SZAs less than $80^{\circ}$. This is because of a decrease in sensitivity to tropospheric $\mathrm{O}_{3}$ in nadir measurements at higher SZAs.

\section{Error analysis}

In this section we estimate the contributions of various error sources to the overall error in the retrieved TOCs. As discussed above, clouds are one of the potential error sources, but their effect has been minimized by using TOZ with cloud fractions of less than or equal to $10 \%$ and limb profiles that are not contaminated with clouds (see Sect. 3.3). The other potential sources of errors are from the knowledge of SOC, TOZ and the effect of the tropopause height. Among these error sources, the error on SOCs dominates. Table 1 shows an estimate of the error sources in the TOC retrieval using the SCIAMACHY LNM technique. The error contribution from the SOCs $\left(X_{\mathrm{Soc}}\right)$, which originates from the retrieval of 
Table 2. Monthly average of global SOC retrieval parameter errors in 2006, $\sigma$ is the assumed parameter uncertainty.

\begin{tabular}{|c|c|c|c|c|c|c|c|c|c|c|c|c|}
\hline \multirow[t]{2}{*}{ Month } & \multicolumn{2}{|c|}{$\begin{array}{l}\text { Error in } \\
\text { temperature } \\
(\sigma=+2 \mathrm{~K})\end{array}$} & \multicolumn{2}{|c|}{$\begin{array}{l}\text { Error in } \\
\text { tangent height } \\
(\sigma=+200 \mathrm{~m})\end{array}$} & \multicolumn{2}{|c|}{$\begin{array}{l}\text { Error in } \mathrm{O}_{3} \\
\text { cross section } \\
\text { (GOME2- } \\
\text { SCIAMACHY) }\end{array}$} & \multicolumn{2}{|c|}{$\begin{array}{l}\text { Error in } \\
\text { albedo } \\
(\sigma=+0.1)\end{array}$} & \multicolumn{2}{|c|}{$\begin{array}{l}\text { Error in } \\
\text { aerosol } \\
(\sigma=-40 \%)\end{array}$} & \multicolumn{2}{|c|}{$\begin{array}{l}\text { Error in } \\
\text { pressure } \\
(\sigma=+2 \%)\end{array}$} \\
\hline & DU & $\%$ & DU & $\%$ & $\mathrm{DU}$ & $\%$ & DU & $\%$ & $\mathrm{DU}$ & $\%$ & DU & $\%$ \\
\hline 200601 & -1.1 & -0.4 & 3.5 & 1.4 & 0.2 & 0.1 & -2.0 & -0.8 & 0.0 & -0.1 & 2.3 & 0.9 \\
\hline 200602 & -1.2 & -0.5 & 3.5 & 1.4 & 0.2 & 0.1 & -2.0 & -0.8 & 0.3 & 0.0 & 2.4 & 0.9 \\
\hline 200603 & -1.3 & -0.5 & 3.8 & 1.4 & 0.2 & 0.1 & -2.1 & -0.8 & 1.0 & 0.2 & 2.6 & 0.9 \\
\hline 200604 & -1.3 & -0.5 & 3.8 & 1.4 & 0.2 & 0.1 & -2.1 & -0.8 & 0.8 & 0.1 & 2.6 & 0.9 \\
\hline 200605 & -1.2 & -0.5 & 3.6 & 1.4 & 0.2 & 0.1 & -2.0 & -0.8 & 0.4 & 0.1 & 2.5 & 0.9 \\
\hline 200606 & -1.2 & -0.5 & 3.4 & 1.3 & 0.2 & 0.1 & -2.0 & -0.8 & 0.4 & 0.1 & 2.5 & 0.9 \\
\hline 200607 & -1.2 & -0.5 & 3.4 & 1.3 & 0.2 & 0.1 & -2.0 & -0.8 & 0.2 & 0.1 & 2.4 & 0.9 \\
\hline 200608 & -1.2 & -0.5 & 3.4 & 1.3 & 0.2 & 0.1 & -2.0 & -0.8 & 0.1 & 0.1 & 2.4 & 0.9 \\
\hline 200609 & -1.2 & -0.5 & 3.4 & 1.3 & 0.2 & 0.1 & -2.0 & -0.8 & 0.2 & 0.1 & 2.4 & 0.9 \\
\hline 200610 & -1.2 & -0.5 & 3.4 & 1.3 & 0.2 & 0.1 & -1.9 & -0.8 & 0.3 & 0.1 & 2.4 & 0.9 \\
\hline 200611 & -1.2 & -0.5 & 3.4 & 1.4 & 0.2 & 0.1 & -1.9 & -0.8 & 0.4 & 0.1 & 2.4 & 0.9 \\
\hline 200612 & -1.2 & -0.5 & 3.4 & 1.4 & 0.2 & 0.1 & -1.9 & -0.8 & 0.6 & 0.2 & 2.4 & 0.9 \\
\hline
\end{tabular}

stratospheric $\mathrm{O}_{3}$ profiles (see Sect. 3.1) was computed from errors resulting from uncertainties in the assumed surface albedo $\left(X_{\mathrm{ab}}\right)$, aerosol extinction profile $\left(X_{\mathrm{ae}}\right), \mathrm{O}_{3}$ absorption cross section $\left(X_{\mathrm{ac}}\right)$, pressure profile $\left(X_{\mathrm{pr}}\right)$, tangent height information $\left(X_{\text {th }}\right)$ and temperature profile $\left(X_{\text {temp }}\right)$.

The contributions from each of the different parameter errors on the retrieved $\mathrm{O}_{3}$ profiles were computed for both hemispheres at different SZAs by using the synthetic retrievals. This is done by applying the following procedure. For each particular parameter, synthetic limb radiances are calculated using a climatological ozone profile (further referred to as the true profile) and a perturbed value of the parameter to initialize the forward model. For example, to investigate the influence of the albedo uncertainty, the surface albedo was increased by 0.1 from its unperturbed value of 0.3. Other model parameters remain the same as used in the routinely retrieval procedure. These simulated radiances are used then as the input for the retrieval instead of the measured spectra and the retrieval is initialized with the unperturbed parameter value. The difference between the ozone profile resulting from this retrieval and the true profile is considered as the contribution from the parameter error. Further details on the synthetic retrievals can be found in Rahpoe et al. (2013).

The influence of the tropopause height on the retrieved TOCs was estimated by using the standard deviation of the tropopause height in a latitude bin as a measure of uncertainty. This approach does not account for the TOC uncertainty resulting from the use of different methods to calculate the tropopause height.

Table 2 presents the monthly averaged contributions from the different parameter errors to the global mean of the retrieved SOCs in 2006. This analysis shows that an increase in albedo of 0.1 leads to an underestimation of SOC by approximately $2 \mathrm{DU}(0.8 \%)$. For a shift in tangent height by $200 \mathrm{~m}$, SOC is overestimated by about $3.5 \mathrm{DU}(1.3 \%)$ and for a decrease in aerosol by $40 \%$ there is an overestimation of SOC by less than $0.5 \mathrm{DU}(0.2 \%)$. A pressure uncertainty of $2 \%$ results in the SOC error of about $2.4 \mathrm{DU}$ $(1 \%)$. A shift in the temperature by $+2 \mathrm{~K}$ leads to an underestimation of SOC by less than $1.2 \mathrm{DU}(0.5 \%)$. To estimate the uncertainty due to errors in $\mathrm{O}_{3}$ absorption cross sections, the SCIAMACHY proto-flight model (PFM) cross sections (Bogumil et al., 2003) used in limb retrievals were replaced by the GOME flight model (FM) cross sections (Burrows et al., 1999). This results in a decrease in the SOCs by about $0.2 \mathrm{DU}(0.09 \%)$, as summarized in Table 2.

The method to estimate the total uncertainty associated with SOC is not straightforward because an assumption of Gaussian distribution for all errors may lead to an underestimation, while the assumption that all errors are additive, overestimates the actual total error. The total uncertainty of the SOC is computed from both the systematic $\left(X_{\mathrm{err}_{1}}\right)$ and random $\left(X_{\mathrm{err}_{2}}\right)$ errors, where the former error is derived from the upper limit estimation as follows:

$X_{\mathrm{err} 1}=\left|X_{\mathrm{ac}}\right|+\left|X_{\mathrm{ae}}\right|+\left|X_{\mathrm{th}}\right|$,

while the random errors are summed up in accordance with the Gaussian rule:

$X_{\mathrm{err}_{2}}=\sqrt{X_{\mathrm{ab}}^{2}+X_{\mathrm{pr}}^{2}+X_{\mathrm{temp}}^{2}+X_{\mathrm{tph}}^{2}}$.

Finally, the total error is estimated as follows:

$X_{\mathrm{soc}}=\sqrt{X_{\mathrm{err}_{1}}^{2}+X_{\mathrm{err}_{2}}^{2}}$. 
In the TOZ retrieval, the total error was estimated by combining contributions from all error sources using Gaussian error propagation (see Coldewey-Egbers et al., 2005, for details). The largest contribution to the error in TOZ was identified to come from the a priori errors associated with the $\mathrm{O}_{3}$ climatology and from the uncertainty in the derived effective scene albedo (Coldewey-Egbers et al., 2005). The extensive validation carried out by Weber et al. (2005) shows that the monthly mean error in the TOZ is mostly about $1 \%$.

Figures 3 and 4 show the monthly mean TOC errors together with the error contributions from SOCs, TOZs as well as the effect of tropopause height on TOCs for January and July 2006, respectively. In January 2006, the SOC error reaches approximately $10 \mathrm{DU}$ at about $50^{\circ} \mathrm{N}$ and decreases to less than $6 \mathrm{DU}$ between $30^{\circ} \mathrm{N}$ and $40^{\circ} \mathrm{N}$. A similar structure is also observed between $30^{\circ} \mathrm{S}$ and $40^{\circ} \mathrm{S}$. Above $60^{\circ}$ in the Southern Hemisphere $(\mathrm{SH})$ the SOC error remains constant at less than $2.5 \mathrm{DU}$ while between $30^{\circ} \mathrm{S}$ and $30^{\circ} \mathrm{N}$ it ranges from 6-8 DU. The strongest error sources in the stratospheric $\mathrm{O}_{3}$ profile retrievals are the uncertainties in the aerosol loading and in the tangent height registration. The latter plays a major role in determining the pattern of the SOC error. In the Northern Hemisphere (NH), the uncertainty in the stratospheric aerosol loading has the largest contribution to the SOC error. For the TOC, the error value increases from about $2.5 \mathrm{DU}$ at $30^{\circ} \mathrm{N}$ to approximately $4 \mathrm{DU}$ at around $50^{\circ} \mathrm{N}$, while between $30^{\circ} \mathrm{N}$ and $30^{\circ} \mathrm{S}$ it lies between 2.5-3.0 DU. The maximum TOC error in the $\mathrm{SH}$ of about $3 \mathrm{DU}$ is observed between $50^{\circ} \mathrm{S}$ and $70^{\circ} \mathrm{S}$. The effect of the tropopause height is also seen to exhibit some latitudinal variability as a result of the $\mathrm{O}_{3}$ variation in the tropopause region with a peak value of about $0.4 \mathrm{DU}$ observed in the $\mathrm{NH}$. The latitudinal variation in the errors is partly due to the error in stratospheric aerosols, whose effect depends on the scattering phase function as well as on the scattering angle (Rahpoe et al., 2013). The parameter uncertainties result in the total error estimation for the mean TOCs of 6.7 DU (22\%). Features similar to those observed in the SOC error for January 2006 are also seen in July 2006 with slightly lower values of SOC error observed between $30^{\circ} \mathrm{N}$ and $50^{\circ} \mathrm{N}$. Similar to January 2006, the error in TOC is slightly higher in the $\mathrm{NH}$ than in the SH. In contrast, the latitudinal variability due to the uncertainty in the tropopause height is higher in the $\mathrm{SH}$ than in the NH.

In general, there is only a small to negligible variation in the monthly average error contributions from the different error sources (see Table 1). The annual average error contribution from SOC is about 6.5 DU ( $<2.5 \%$ of SOC). The mean TOZ error is less than $3 \mathrm{DU}\left(\sim 1 \%\right.$ of TOZ). The $\mathrm{O}_{3}$ error caused by tropopause height errors is about $0.1 \mathrm{DU}(\sim 0.8 \%$ of TOC). The rather small errors in TOZs and SOCs still result in fairly large errors in the retrieved TOCs, resulting in a mean error of about $7 \mathrm{DU}$, which is about $24 \%$ of the mean TOC.

\section{Intercomparisons of SCIAMACHY tropospheric ozone}

\subsection{Time series of tropospheric ozone columns from SCIAMACHY, TES, OMI/MLS and ozonesondes}

The accuracy of the tropospheric $\mathrm{O}_{3}$ retrieved from SCIAMACHY was investigated by comparing with the TOCs from balloon-borne ozonesondes, and those retrieved from TES and the combined OMI/MLS data products. An overview of the comparison results is presented in Table 3. The comparison of the TOCs retrieved from SCIAMACHY or other remote sensing instrumentation with those from the ozonesondes requires care. This is because the latter provide $\mathrm{O}_{3}$ measurements along the trajectory paths of the sonde. These are different from satellite measurements that yield averages above a ground scene. However, the quality of the ozonesonde measurements is well established. Furthermore, the determination of TOC from ozonesonde measurements does not require a priori information. Therefore, ozonesonde measurements are used as a benchmark in this study to evaluate SCIAMACHY TOC retrievals.

This study uses ozonesonde data provided by the Southern Hemisphere ADditional OZonseondes (SHADOZ) and the World Ozone and Ultraviolet Radiation Data Centre (WOUDC). The sonde stations included in the comparisons are listed in Table 3. Monthly means and standard deviations of SCIAMACHY TOCs were compared with collocated monthly mean TOCs from ozonesondes, TES and OMI/MLS using the collocation criteria of $\pm 5^{\circ}$ in latitude and $\pm 10^{\circ}$ in longitude. The standard deviation of the data shown in the table represents an aggregate of the variability of tropospheric $\mathrm{O}_{3}$ values and associated measurement errors. The ozonesonde data sets overlapping in time with the SCIAMACHY observation period extend from 2003 to 2011. However, due to the unavailability of measurements from TES and OMI/MLS before September 2004, the comparisons were limited to the period 2004-2011 for which all measurements were available.

Figures 6-11 show TOC anomaly (TOCA) time series for some selected ozonesonde stations. The anomalies were determined by subtracting from each individual time series, the mean TOC values calculated over the considered period. This approach removes inter-instrumental biases, thus allowing the seasonal variations to be compared more easily. The TOCA time series from the four instruments, SCIAMACHY (black), ozonesonde (red), TES (violet) and OMI/MLS (green) show a pronounced seasonal cycle with maximum values during spring and summer with slightly different amplitudes.

Over Bratt's Lake $\left(50.20^{\circ} \mathrm{N}, 104.70^{\circ} \mathrm{W}\right)$ (Fig. 6), ozonesonde measurements show generally lower minima. They exhibit higher anomalies of up to +13 DU than the satellite instruments mostly during early spring of 2005 and early summer months of 2011. The seasonality of OMI/MLS 
Table 3. Comparisons of tropospheric ozone columns from SCIAMACHY, ozonesondes, TES and OMI/MLS for some selected stations over the entire time series (2004-2011). Mean value and standard deviation (SD) as well as the relative difference of each satellite data product using ozonesonde as the reference are shown.

\begin{tabular}{|c|c|c|c|c|c|c|c|c|c|c|}
\hline Station name & $\begin{array}{l}\text { Collocated } \\
\text { points }\end{array}$ & Latitude & Longitude & $\begin{array}{l}\text { Mean value } \\
\text { and SD of } \\
\text { TOC from } \\
\text { sondes } \\
\text { (DU) }\end{array}$ & $\begin{array}{l}\text { Mean value } \\
\text { and SD of } \\
\text { TOC from } \\
\text { SCIA- } \\
\text { MACHY } \\
\text { (DU) }\end{array}$ & $\begin{array}{l}\text { Mean value } \\
\text { and SD of } \\
\text { TOC from } \\
\text { TES (DU) }\end{array}$ & $\begin{array}{l}\text { Mean value } \\
\text { and SD of } \\
\text { TOC from } \\
\text { OMI/MLS } \\
\text { (DU) }\end{array}$ & $\begin{array}{l}\text { Mean } \\
\text { value } \\
\text { of TOC } \\
\text { rel. } \\
\text { diff. } \\
\text { (SCIA- } \\
\text { MACHY) }\end{array}$ & $\begin{array}{l}\text { Mean } \\
\text { value } \\
\text { of TOC } \\
\text { rel. } \\
\text { diff. } \\
\text { (TES) }\end{array}$ & $\begin{array}{l}\text { Mean } \\
\text { value } \\
\text { of TOC } \\
\text { rel. } \\
\text { diff. } \\
\text { (OMI/ } \\
\text { MLS) }\end{array}$ \\
\hline 1. Lerwick & 62 & 60.13 & 358.82 & $33.4 \pm 4.7$ & $40.6 \pm 6.8$ & $38.2 \pm 2.6$ & $30.1 \pm 4.1$ & 0.22 & 0.15 & -0.10 \\
\hline 2. Churchill & 57 & 58.75 & 265.93 & $31.2 \pm 4.6$ & $34.8 \pm 7.6$ & $35.4 \pm 2.4$ & $30.2 \pm 4.5$ & 0.11 & 0.13 & -0.03 \\
\hline 3. Edmonton & 62 & 53.55 & 245.90 & $28.3 \pm 3.9$ & $34.4 \pm 5.5$ & $34.4 \pm 2.4$ & $25.9 \pm 3.3$ & 0.22 & 0.22 & -0.08 \\
\hline 4. Goose Bay & 59 & 53.32 & 299.70 & $32.1 \pm 5.2$ & $34.8 \pm 6.8$ & $38.0 \pm 2.8$ & $30.7 \pm 3.2$ & 0.08 & 0.18 & -0.04 \\
\hline 5. Legionowo & 71 & 52.40 & 020.97 & $36.1 \pm 7.0$ & $38.2 \pm 4.9$ & $41.1 \pm 4.9$ & $29.0 \pm 4.5$ & 0.06 & 0.14 & -0.20 \\
\hline 6. De Bilt & 75 & 52.10 & 005.18 & $35.4 \pm 5.5$ & $41.3 \pm 6.9$ & $41.2 \pm 4.2$ & $29.7 \pm 4.1$ & 0.17 & 0.16 & -0.16 \\
\hline 7. Valentia & 48 & 51.93 & 349.75 & $37.4 \pm 5.1$ & $34.9 \pm 3.6$ & $40.8 \pm 3.1$ & $31.5 \pm 4.2$ & -0.07 & 0.09 & -0.16 \\
\hline 8. Uccle & 78 & 50.80 & 004.35 & $35.7 \pm 6.2$ & $41.4 \pm 6.8$ & $41.3 \pm 4.3$ & $29.8 \pm 4.0$ & 0.16 & 0.16 & -0.17 \\
\hline 9. Bratt's Lake & 78 & 50.20 & 255.30 & $32.7 \pm 5.2$ & $34.4 \pm 3.8$ & $37.2 \pm 3.8$ & $27.3 \pm 2.6$ & 0.04 & 0.16 & -0.18 \\
\hline 10. Praha & 26 & 50.02 & 014.45 & $34.4 \pm 4.8$ & $38.8 \pm 6.7$ & $38.3 \pm 3.0$ & $27.0 \pm 3.8$ & 0.13 & 0.11 & -0.21 \\
\hline 11. Kelowna & 77 & 49.93 & 240.60 & $32.9 \pm 5.2$ & $33.3 \pm 5.1$ & $36.2 \pm 2.8$ & $26.2 \pm 3.9$ & 0.01 & 0.10 & -0.21 \\
\hline 12. Payerne & 82 & 46.49 & 006.57 & $33.6 \pm 6.2$ & $43.9 \pm 6.4$ & $41.7 \pm 5.2$ & $29.5 \pm 4.6$ & 0.31 & 0.24 & -0.12 \\
\hline 13. Egbert & 74 & 44.23 & 280.22 & $37.4 \pm 7.2$ & $37.8 \pm 4.9$ & $42.9 \pm 5.4$ & $30.8 \pm 5.0$ & 0.01 & 0.15 & -0.18 \\
\hline 14. Yarmouth & 63 & 43.87 & 293.89 & $38.9 \pm 7.8$ & $40.5 \pm 6.4$ & $43.1 \pm 5.5$ & $32.5 \pm 5.7$ & 0.04 & 0.14 & -0.17 \\
\hline 15. Sapporo & 82 & 43.10 & 141.30 & $35.3 \pm 8.7$ & $40.4 \pm 8.9$ & $42.6 \pm 6.3$ & $34.3 \pm 6.5$ & 0.14 & 0.21 & -0.03 \\
\hline 16. Madrid & 81 & 40.45 & 356.28 & $34.8 \pm 6.4$ & $40.3 \pm 5.8$ & $42.1 \pm 5.1$ & $31.1 \pm 6.3$ & 0.16 & 0.21 & -0.11 \\
\hline 17. Ankara & 78 & 39.95 & 032.88 & $35.6 \pm 9.9$ & $39.4 \pm 5.6$ & $44.6 \pm 9.2$ & $33.2 \pm 8.5$ & 0.10 & 0.25 & -0.07 \\
\hline 18. Wallops & 79 & 37.93 & 284.52 & $41.5 \pm 8.1$ & $43.3 \pm 6.0$ & $45.5 \pm 5.5$ & $33.1 \pm 6.7$ & 0.04 & 0.10 & -0.20 \\
\hline 19. Tsukuba & 82 & 36.10 & 140.10 & $41.5 \pm 9.3$ & $41.6 \pm 5.6$ & $43.5 \pm 3.4$ & $33.7 \pm 5.2$ & 0.01 & 0.09 & -0.18 \\
\hline 20. Huntsville & 38 & 34.72 & 273.36 & $40.3 \pm 8.4$ & $40.1 \pm 5.3$ & $45.0 \pm 4.9$ & $32.4 \pm 7.2$ & 0.00 & 0.12 & -0.20 \\
\hline 21. Isfahan & 50 & 32.51 & 051.70 & $37.3 \pm 9.1$ & $33.0 \pm 4.7$ & $41.8 \pm 4.9$ & $31.0 \pm 6.6$ & -0.12 & 0.12 & -0.17 \\
\hline 22. Naha & 82 & 26.20 & 127.70 & $38.9 \pm 7.7$ & $39.9 \pm 6.6$ & $39.4 \pm 4.8$ & $32.6 \pm 4.8$ & 0.02 & 0.01 & -0.16 \\
\hline 23. Hong Kong & 81 & 22.31 & 114.17 & $38.9 \pm 6.3$ & $38.6 \pm 6.3$ & $39.1 \pm 4.0$ & $32.6 \pm 4.4$ & -0.01 & 0.01 & -0.16 \\
\hline 24. Hanoi & 47 & 21.01 & 105.80 & $36.8 \pm 5.9$ & $34.8 \pm 4.3$ & $38.1 \pm 3.8$ & $30.1 \pm 4.2$ & -0.05 & 0.03 & -0.18 \\
\hline 25. Hilo & 77 & 19.43 & 204.96 & $33.6 \pm 6.2$ & $33.7 \pm 4.2$ & $34.6 \pm 3.9$ & $28.2 \pm 3.9$ & 0.00 & 0.08 & -0.13 \\
\hline 26. Costa Rica & 67 & 9.98 & 275.79 & $25.3 \pm 3.6$ & $25.3 \pm 4.4$ & $29.2 \pm 1.7$ & $25.1 \pm 2.2$ & 0.00 & 0.15 & -0.01 \\
\hline 27. Paramaribo & 69 & 5.81 & 304.79 & $26.3 \pm 6.5$ & $26.2 \pm 5.1$ & $29.9 \pm 2.6$ & $25.1 \pm 2.6$ & 0.00 & 0.14 & -0.04 \\
\hline 28. Sepang & 62 & 2.73 & 101.70 & $24.8 \pm 3.9$ & $25.5 \pm 5.3$ & $24.6 \pm 2.3$ & $20.9 \pm 3.1$ & 0.03 & -0.01 & -0.16 \\
\hline 29. San Cristóbal & 31 & -0.92 & 270.38 & $25.8 \pm 5.7$ & $27.4 \pm 5.0$ & $29.1 \pm 3.7$ & $25.2 \pm 3.8$ & 0.06 & 0.13 & -0.02 \\
\hline 30. Nairobi & 69 & -1.27 & 036.80 & $28.2 \pm 3.6$ & $27.0 \pm 3.4$ & $33.5 \pm 3.3$ & $27.3 \pm 2.9$ & -0.04 & 0.19 & -0.03 \\
\hline 31. Natal & 72 & -5.49 & 324.74 & $34.5 \pm 8.3$ & $31.5 \pm 5.6$ & $36.2 \pm 6.2$ & $30.4 \pm 5.1$ & -0.16 & 0.07 & -0.10 \\
\hline 32. Java & 67 & -7.50 & 112.60 & $23.7 \pm 6.5$ & $23.9 \pm 3.9$ & $25.1 \pm 4.1$ & $21.7 \pm 4.1$ & 0.01 & 0.06 & -0.09 \\
\hline 33. Watukosek & 52 & -7.57 & 112.65 & $23.4 \pm 6.5$ & $25.0 \pm 4.4$ & $25.1 \pm 4.3$ & $22.0 \pm 4.3$ & 0.07 & 0.07 & -0.06 \\
\hline 34. Ascension & 63 & -7.98 & 345.58 & $38.2 \pm 7.7$ & $32.4 \pm 8.6$ & $40.5 \pm 6.4$ & $34.6 \pm 5.4$ & -0.15 & 0.06 & -0.09 \\
\hline 35. Samoa & 71 & -14.23 & 189.44 & $22.2 \pm 5.7$ & $25.0 \pm 4.9$ & $23.9 \pm 4.2$ & $19.6 \pm 4.0$ & 0.12 & 0.07 & -0.12 \\
\hline 36. Fiji & 43 & -18.13 & 178.40 & $23.9 \pm 7.4$ & $30.0 \pm 5.4$ & $27.8 \pm 5.0$ & $23.0 \pm 4.2$ & 0.25 & 0.16 & -0.04 \\
\hline 37. La Réunion & 72 & -21.06 & 055.48 & $41.1 \pm 8.6$ & $35.4 \pm 6.1$ & $40.0 \pm 6.8$ & $33.6 \pm 6.0$ & -0.14 & -0.03 & -0.18 \\
\hline 38. Irene & 31 & -25.90 & 028.22 & $37.8 \pm 7.1$ & $33.8 \pm 7.0$ & $38.5 \pm 5.2$ & $32.1 \pm 4.7$ & -0.11 & 0.02 & -0.15 \\
\hline 39. Broadmeadows & 62 & -37.68 & 144.95 & $28.7 \pm 4.9$ & $31.2 \pm 5.6$ & $33.8 \pm 5.0$ & $27.8 \pm 3.0$ & 0.07 & 0.07 & -0.10 \\
\hline 40. Lauder & 50 & -45.04 & 169.68 & $23.1 \pm 3.2$ & $27.8 \pm 5.8$ & $25.5 \pm 2.2$ & $22.5 \pm 2.6$ & 0.20 & 0.10 & -0.03 \\
\hline 41. Macquarie & 62 & -54.50 & 158.97 & $22.7 \pm 3.4$ & $24.7 \pm 3.4$ & $23.2 \pm 3.5$ & $24.6 \pm 3.2$ & 0.15 & 0.02 & 0.12 \\
\hline 42. Ushuaia & 21 & -54.85 & 291.69 & $21.0 \pm 3.6$ & $25.2 \pm 5.9$ & $23.8 \pm 3.2$ & $25.2 \pm 3.5$ & 0.20 & 0.13 & 0.20 \\
\hline 43. Marambio & 45 & -64.23 & 303.38 & $19.0 \pm 4.0$ & $21.3 \pm 4.3$ & $21.4 \pm 6.2$ & $22.9 \pm 4.3$ & 0.12 & 0.12 & 0.20 \\
\hline \multicolumn{4}{|c|}{ Mean value of tropospheric ozone } & $32.2 \pm 6.4$ & $33.8 \pm 5.7$ & $35.7 \pm 4.5$ & $28.5 \pm 4.6$ & 0.06 & 0.11 & -0.10 \\
\hline
\end{tabular}



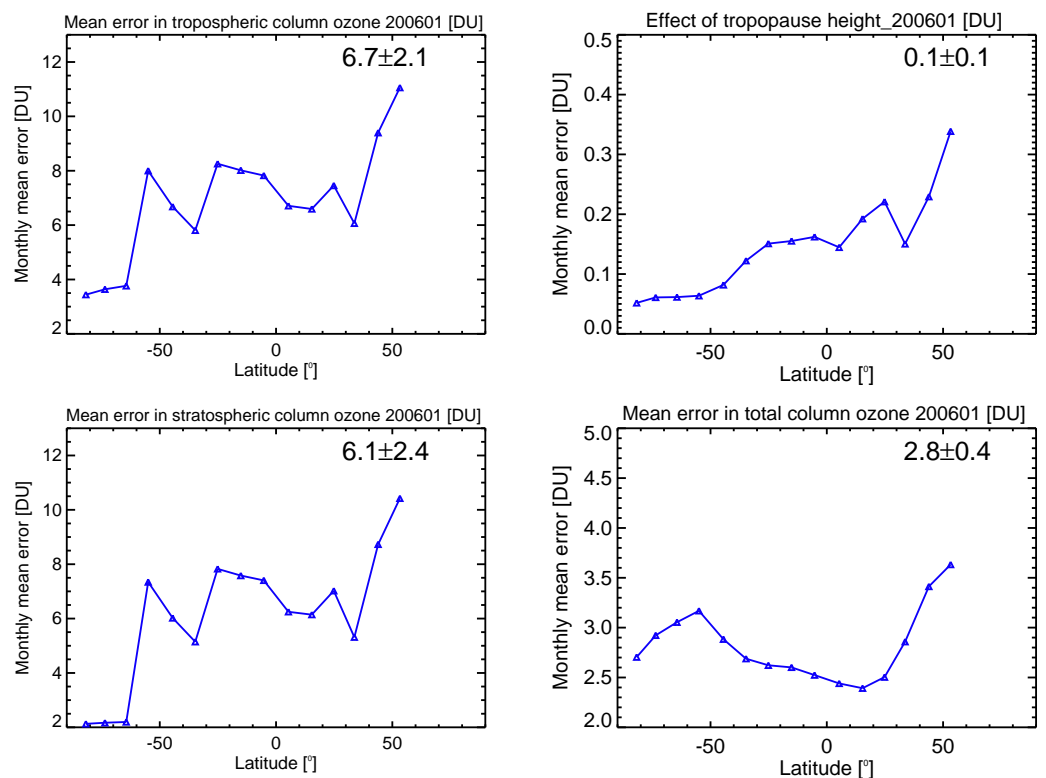

Figure 3. Top panels from left to right: monthly mean zonal mean error in tropospheric ozone columns (TOCs) and contribution from errors in tropopause height for January 2006. Bottom panels from left to right: monthly mean zonal mean error of stratospheric ozone column (SOC) and total ozone (TOZ) in January 2006, contributing to the error in tropospheric ozone columns (TOC).
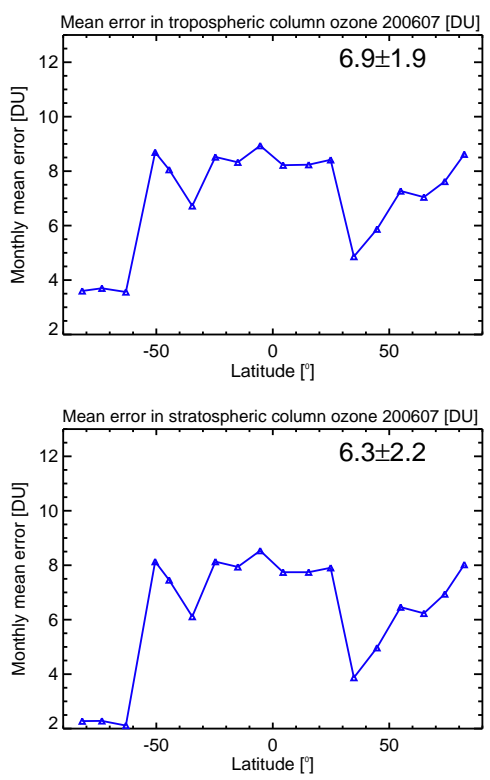

Figure 4. As Fig. 3 but for July 2006.

becomes different from those of the other instruments after 2009. The values from SCIAMACHY are too low in autumn 2010 and those of both TES and OMI/MLS are too low in spring and summer 2004. TES TOCA values over Bratt's Lake are slightly higher than the values from the other satellite instruments during late spring and summer months of 2010 and 2011. Above Tsukuba $\left(36.10^{\circ} \mathrm{N}, 140.10^{\circ} \mathrm{E}\right)$, (Fig. 7), SCIAMACHY TOCA values are higher than those from the other satellite instruments during late spring and
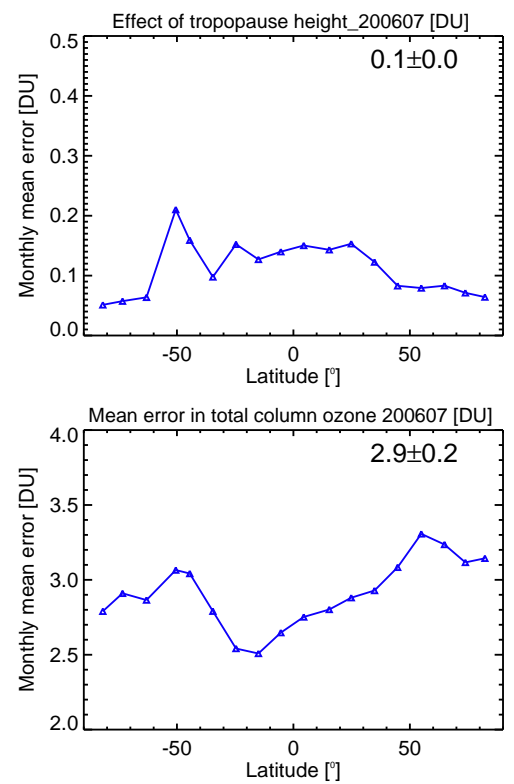

early summer of 2005. On average, the amplitude of the seasonal cycle of ozonesonde measurements in this region is higher than that from the other instruments. Above Hilo (Fig. 8), the peak TOCA values observed during JanuaryApril in ozonesonde measurements are higher than those of the satellite instruments. SCIAMACHY TOCA values are higher than the values of the other satellites during December 2010. Over Natal (Fig. 9), ozonesonde measurements show higher amplitude of the seasonal variation compared 


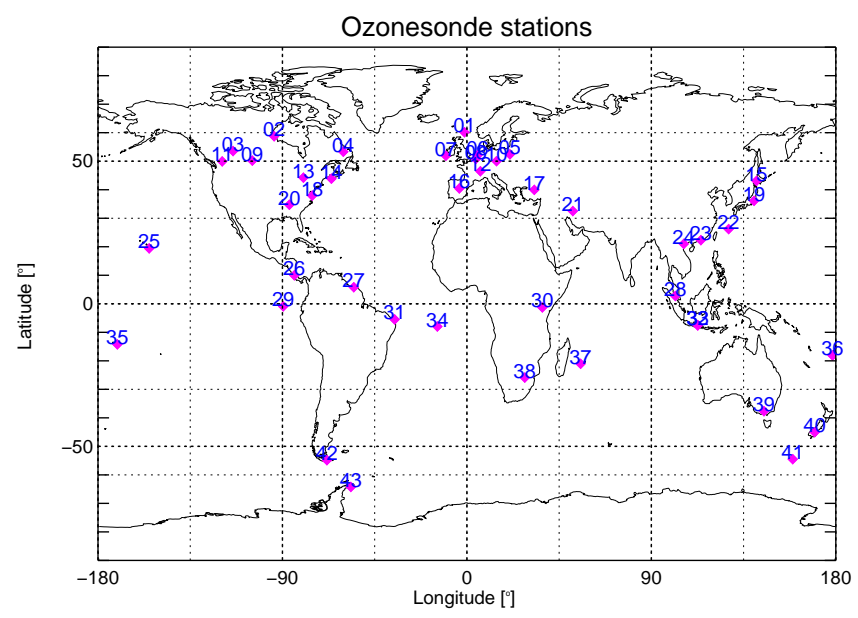

Figure 5. World map showing ozonesonde stations (station numbers are listed in Table 4) used in this study.

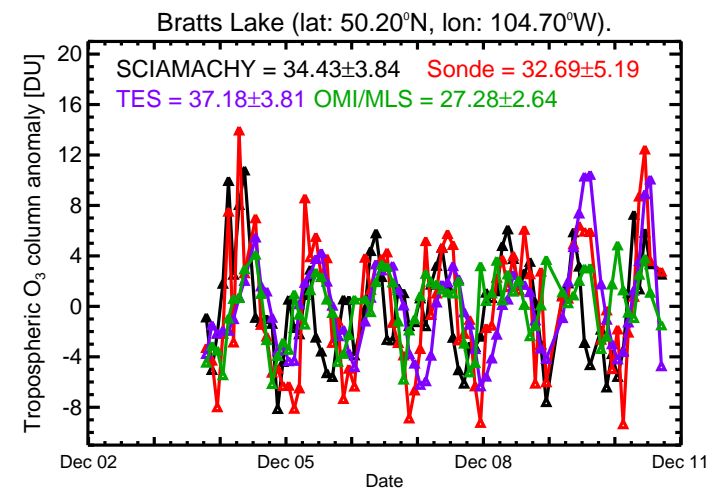

Figure 6. Monthly mean TOC anomaly in Dobson units (DU) from SCIAMACHY (black), ozonesondes (red), TES (violet) and OMI/MLS (green) over Bratt's Lake $\left(50.20^{\circ} \mathrm{N}, 104.70^{\circ} \mathrm{W}\right)$.

to the measurements from the satellite instruments except for 2007. Above Broadmeadows (Fig. 10), TES values are higher than those of the other instruments in the late boreal summer and autumn of 2010 and 2011. SCIAMACHY values exhibit higher maxima than those of OMI/MLS and TES during boreal autumn. Above Macquarie Island (Fig. 11), SCIAMACHY values are lower compared to the results from the other instruments mostly during boreal summer months.

For all satellite data sets, the relative differences with respect to ozonesondes for all considered stations are summarized in Table 3. The results show a good agreement for all data sets with mean relative differences of $0.06,0.11$ and -0.10 for SCIAMACHY, TES and OMI/MLS, respectively. The climatological characteristics exhibited by the ozonesondes may differ due to their location. Therefore, the comparison of the tropospheric $\mathrm{O}_{3}$ retrieved from SCIAMACHY with both in situ and other satellite measurements is necessary. For most of the stations in both hemispheres (Fig. 5), the monthly mean tropospheric $\mathrm{O}_{3}$ over the entire time series

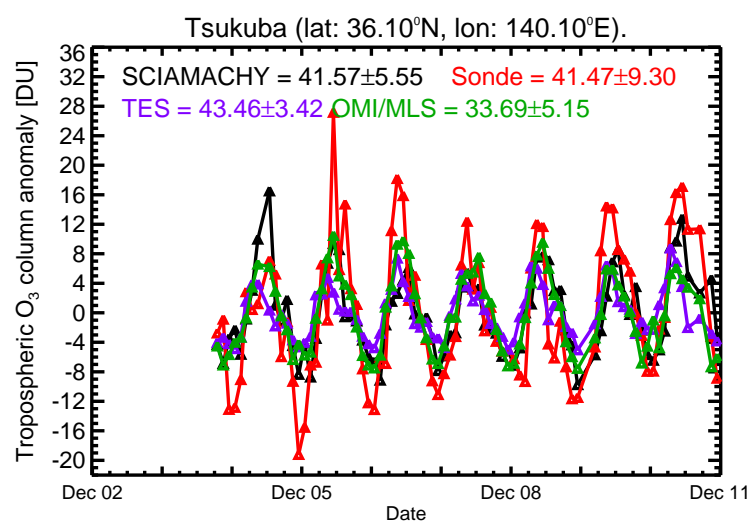

Figure 7. As Fig. 6, but over Tsukuba $\left(36.10^{\circ} \mathrm{N}, 140.10^{\circ} \mathrm{E}\right)$.

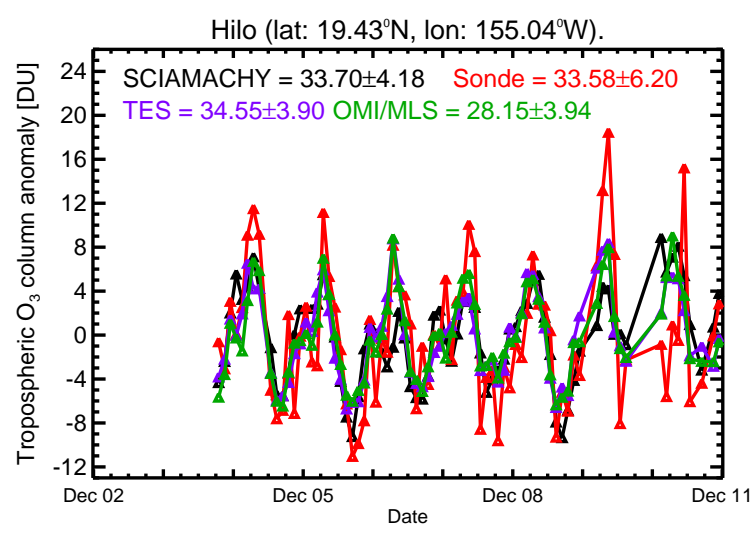

Figure 8. As Fig. 6, but over Hilo $\left(19.72^{\circ} \mathrm{N}, 155.04^{\circ} \mathrm{W}\right)$.

from the four instruments agree in terms of magnitude and annual variation with some differences, which are within the error bars as shown in Table 3. Despite an overall good agreement there are still significant discrepancies between the time series from different instruments. Possible explanations are as follows. Comparisons of TOC values from satellites with ozonesonde data, which are sparse, are prone to variability in the dynamically active subtropics, where rapid fluctuations in the tropopause heights occur. Such comparisons exhibit a lot of scatter and the regression line may deviate from the line of unity (Ziemke et al., 2006). Differences in the definition of the tropopause height can also contribute to differences in the tropospheric $\mathrm{O}_{3}$ from the different instruments. Further issues might result from differences in the retrieval algorithms and filtering of data affected by clouds. The comparison of TES tropospheric $\mathrm{O}_{3}$ with other data products suffers from a sampling bias because of low number of measurements per month (Toohey et al., 2013). Despite a possible bias (Nassar et al., 2008), the TES data product is valuable, because of a lack of tropospheric $\mathrm{O}_{3}$ data products from space-borne instruments. As a result of the limited vertical resolution of the TES TOC retrieval, information from the stratospheric true state can be smeared into the troposphere. However, the 


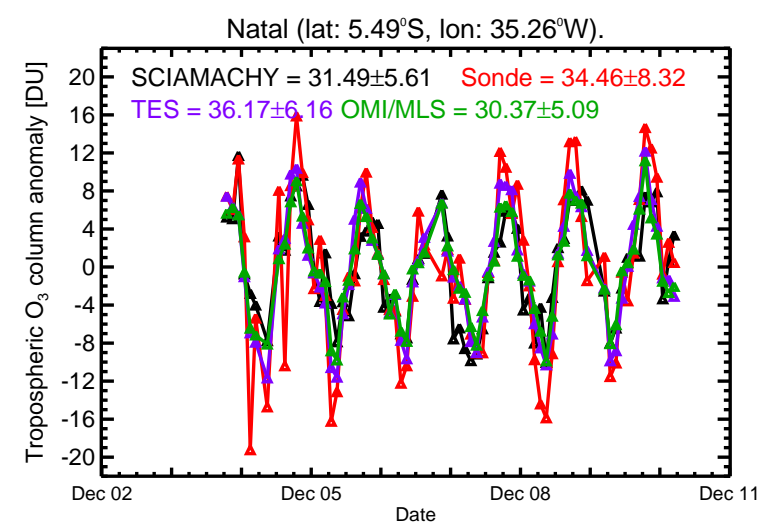

Figure 9. As Fig. 6, but over Natal $\left(5.42^{\circ} \mathrm{S}, 35.38^{\circ} \mathrm{W}\right)$.

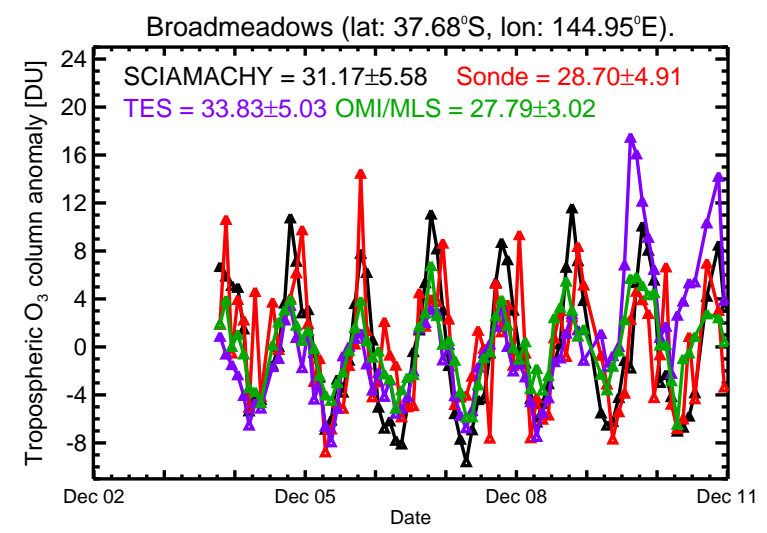

Figure 10. As Fig. 6, but over Broadmeadows $\left(37.68^{\circ} \mathrm{S}\right.$, $\left.144.95^{\circ} \mathrm{E}\right)$.

error caused by this effect is included in the error estimate of the TES TOC data product used in this analysis (Osterman et al., 2008). Cloudy data are rejected in both SCIAMACHY and OMI/MLS tropospheric $\mathrm{O}_{3}$ retrievals (Ziemke et al., 2006) in a similar way. Thus "clear-sky" to "all-sky" biases are not expected. For TES measurements, a "clearsky" to "all-sky" bias might exist but it is expected to be less significant than the overall sampling bias. The error arising from the time $(\sim 7 \mathrm{~min})$ between limb and nadir observations for SCIAMACHY as well as for MLS and OMI is assumed to be negligible because of the short time period and the coarse horizontal resolution of the limb measurements.

\subsection{Zonal distribution of tropospheric ozone columns from SCIAMACHY, TES and OMI/MLS}

The zonal distribution of TOCs is useful as it reveals regions of $\mathrm{O}_{3}$ production and destruction. It facilitates the identification of features that might be hidden or amplified in colour maps, which could result from the resolution or changes in the colour scale. Figure 12 shows plots of OMI/MLS, SCIAMACHY and TES TOC values as

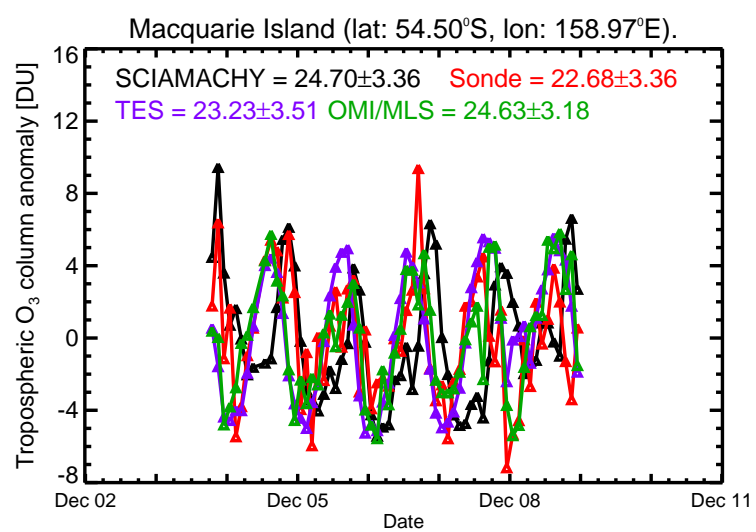

Figure 11. As Fig. 6, but over Macquarie Island $\left(54.50^{\circ} \mathrm{S}\right.$, $\left.158.95^{\circ} \mathrm{E}\right)$.

functions of longitude for different latitude bands, $60^{\circ} \mathrm{S}$ $40^{\circ} \mathrm{S}, 20^{\circ} \mathrm{S}-20^{\circ} \mathrm{N}$, and $40^{\circ} \mathrm{N}-60^{\circ} \mathrm{N}$ in different seasons: winter (December-January-February (DJF)), summer (JuneJuly-August (JJA)), spring (March-April-May (MAM)) and autumn (September-October-November (SON)), averaged over a period of 6 years from December 2005 to November 2011 . In the left panels $\left(60^{\circ} \mathrm{S}-40^{\circ} \mathrm{S}\right)$, the spatial variability of the TOCs from SCIAMACHY and OMI/MLS is similar especially during MAM while TES shows less variation in all seasons. The zonal variation caused by the presence of the Andes mountains at around $70^{\circ} \mathrm{W}$ is well captured by both SCIAMACHY and OMI/MLS except for boreal summer, where the variation observed from OMI/MLS is low. SCIAMACHY captured enhanced $\mathrm{O}_{3}$ values between $20^{\circ} \mathrm{W}$ and $170^{\circ} \mathrm{E}$, which are pronounced in boreal winter and autumn. The enhanced $\mathrm{O}_{3}$ values can be explained by stratosphere-troposphere exchange (STE) processes, as well as by the transport of $\mathrm{O}_{3}$ rich air from the tropical south Atlantic during autumn months (e.g. Chandra et al., 2002; Thompson et al., 2007; Pfister et al., 2008; Stevenson et al., 2006). The spatial variation between $20^{\circ} \mathrm{E}$ and $20^{\circ} \mathrm{W}$, as observed from OMI/MLS during autumn, is higher than that from SCIAMACHY.

In the middle panels $\left(20^{\circ} \mathrm{S}-20^{\circ} \mathrm{N}\right)$, all satellite instruments show the persistent wave-one feature of the tropical troposphere, i.e. TOCs changing from high values in the tropical Atlantic to low values in the tropical Pacific (e.g. Chandra et al., 2002; Thompson et al., 2003; Martin et al., 2002). This feature is clearly visible in all the seasons and is most pronounced during autumn. The wave-one pattern in TOCs is caused by several factors including lightning in both Africa and South America, biomass burning, and deep convection in the Pacific region. These are coupled with vertical injection of low marine boundary layer tropospheric $\mathrm{O}_{3}$ into the middle and upper troposphere (the large-scale Walker Circulation) (e.g. Thompson et al., 2000; Chandra et al., 2002, 2003; Edwards et al., 2003). In this latitude band, TES tropospheric 

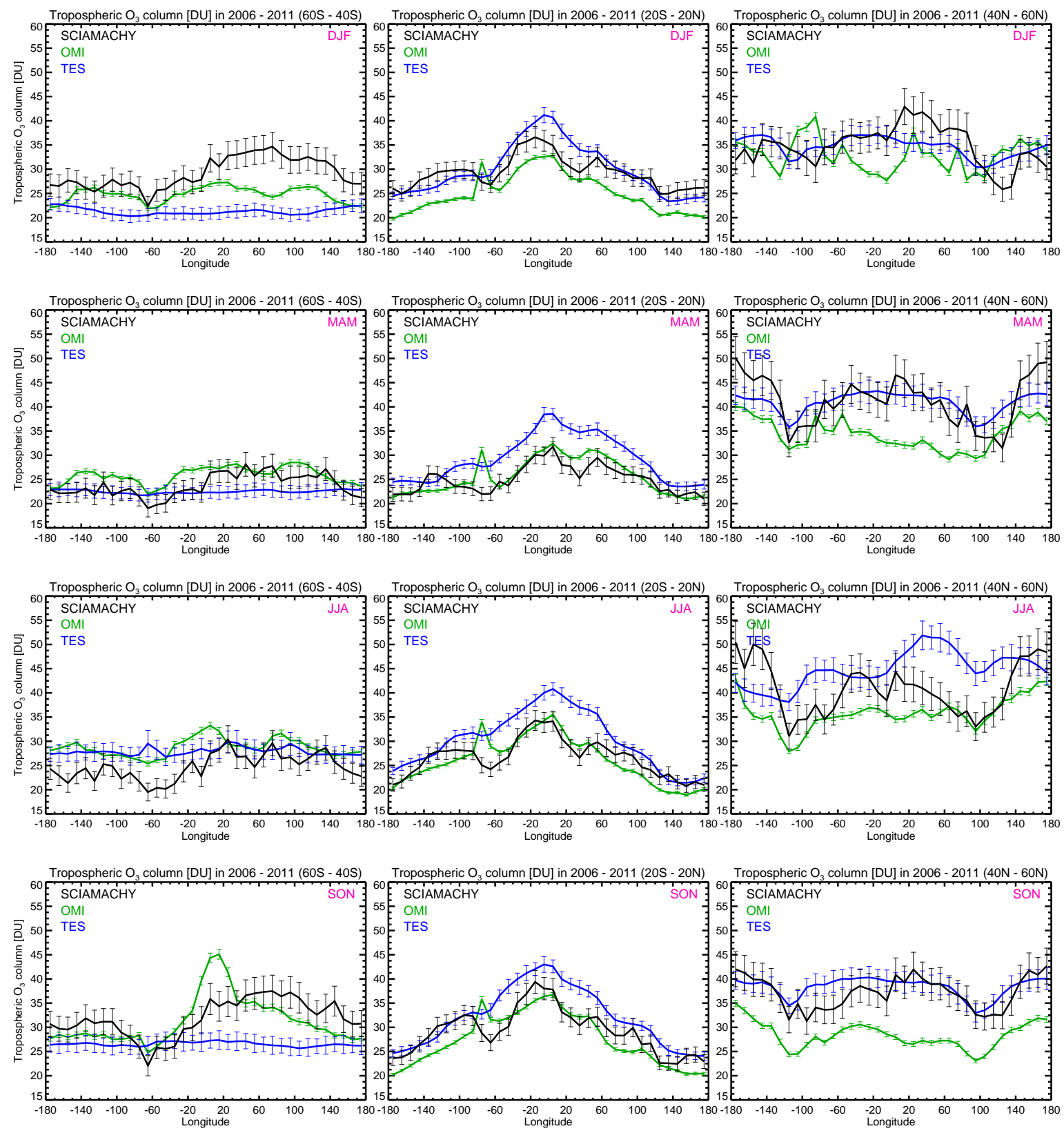

Figure 12. Line plots of TOC (in DU) as a function of longitude retrieved from the measurements of OMI/MLS, SCIAMACHY and TES; from left to right are the latitude bins $60-40^{\circ} \mathrm{S}, 20^{\circ} \mathrm{S}-20^{\circ} \mathrm{N}$ and $40-60^{\circ} \mathrm{N}$, respectively averaged from December 2005 to November 2011 ; from the top panels to the bottom panels; the average composite for December-January-February, March-April-May, June-July-August and September-October-November are shown. Also included in the plots are $\pm 2 \sigma$ vertical bars used as estimates of variability of monthly zonal means, where $\sigma$ is the calculated 6-year rms standard error of the mean.

$\mathrm{O}_{3}$ values in the tropical Atlantic between $20^{\circ} \mathrm{W}$ and $20^{\circ} \mathrm{E}$ are higher for all seasons than the values from other satellite instruments.

In the right panels $\left(40^{\circ} \mathrm{N}-60^{\circ} \mathrm{N}\right)$, similar zonal variation is observed from SCIAMACHY and TES measurements in the spring and autumn months, while in other seasons all instruments provide different results. The largest TOC values are found in this latitude zone. The year-round spatial variability in this zonal band can be associated with several sources including STE, lightning, biomass burning, and combustion of fossil fuels (e.g. Logan, 1985; Zhang et al., 2011; Stohl et al., 2007, 2003; Chandra et al., 2004). 

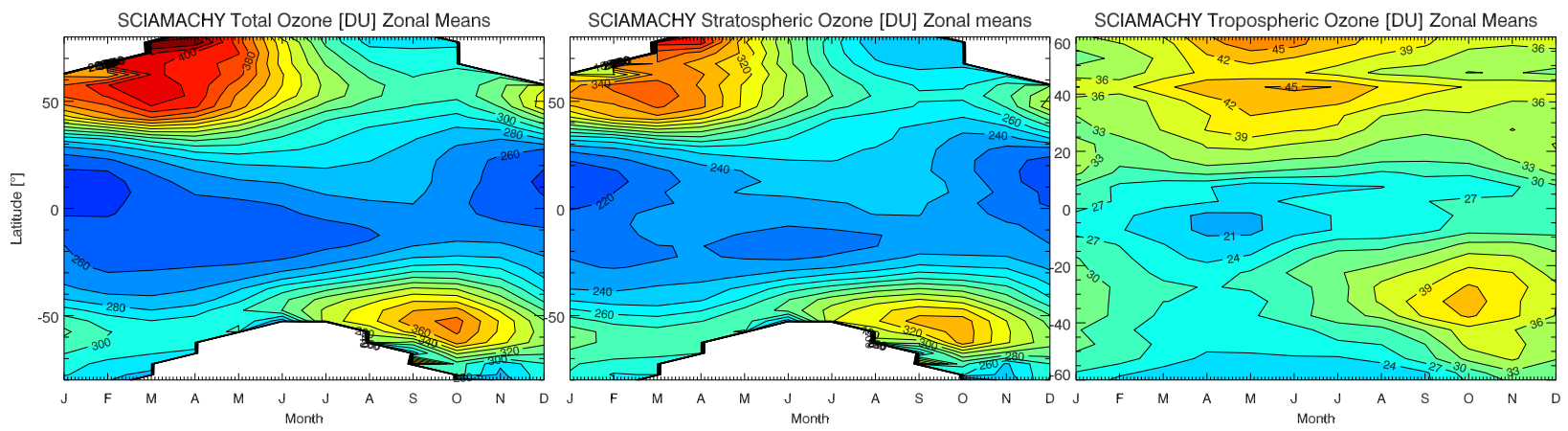

Figure 13. Zonal mean climatology of ozone in Dobson units; from left to right: total ozone column, stratospheric ozone column and tropospheric ozone column derived from October 2004 to December 2010 from SCIAMACHY measurements in $5^{\circ}$ latitude bins.

\subsection{Zonal mean climatology of ozone}

A zonal mean climatology of tropospheric $\mathrm{O}_{3}$ is useful for evaluating chemistry transport models, because it might reveal possible offsets or seasonal and annual-cycle differences. Figure 13 shows the 6-year climatology of zonal mean TOZ (left), SOC (middle) and TOC (right) from SCIAMACHY instrument as a function of latitude and the month, averaged over the period from October 2004 to December 2010. Note the difference in the $y$-axis range in the plots. In Fig. 13 (left), TOZ maximizes in the $\mathrm{NH}$ between $70^{\circ} \mathrm{N}-80^{\circ} \mathrm{N}$ in March-May (>410DU) and in the $\mathrm{SH}$ between $50^{\circ} \mathrm{S}-70^{\circ} \mathrm{S}$ during September-mid-October ( $>360$ DU). Lowest TOZ occurs in December-February between latitude $0-20^{\circ} \mathrm{N}(<250 \mathrm{DU})$ and in the tropics and midlatitudes $(<280 \mathrm{DU})$. The high SOC and TOZ values in the extratropics during winter/spring are due to $\mathrm{O}_{3}$ transport as a result of the Brewer-Dobson circulation (e.g. Weber et al., 2011). In Fig. 13 (middle), the largest values of SOC occur in the $\mathrm{NH}$ in the latitudes between $70^{\circ} \mathrm{N}-$ $80^{\circ} \mathrm{N}$ in mid-February to late April ( $>360 \mathrm{DU}$ ) and in the $\mathrm{SH}$ at latitudes of $50^{\circ} \mathrm{S}-70^{\circ} \mathrm{S}$ during September-November (>320 DU). The high SOCs in the NH are associated with high $\mathrm{O}_{3}$ over North America and central Asia. Lowest SOCs occur between $0-20^{\circ} \mathrm{N}$ in December-February in the tropics $(<240$ DU). All these features observed in Fig. 13 (middle) are present also in Fig. 10 of Ziemke et al. (2011). In Fig. 13 (right), the lowest amounts of tropospheric $\mathrm{O}_{3}$ of less than $21 \mathrm{DU}$ occur in the SH tropics between $0-10^{\circ} \mathrm{S}$ during March-May. Low $\mathrm{O}_{3}$ values are also observed in the tropics, in the SH extratropics and midlatitudes in January-October $(<27 \mathrm{DU})$. Similar features in the region around $10^{\circ} \mathrm{S}$ are clearly observed in Fig. 7 of Ziemke et al. (2011). The largest TOCs occur in the NH subtropics and midlatitudes during March-August (>42 DU) and in the SH subtropics during September-November ( $>39 \mathrm{DU}$ ). In the NH, the transition of tropospheric $\mathrm{O}_{3}$ peak values from the tropical/subtropical region during March-May to peak $\mathrm{O}_{3}$ values between JuneAugust in the midlatitudes is observed in a similar extent as by Ziemke et al. (2011). This northward shift from spring to summer in the $\mathrm{NH}$ is likely related to spring and summer STE as well as tropospheric $\mathrm{O}_{3}$ anthropogenically produced during summer months (Chandra et al., 2004; Logan, 1985; Stohl et al., 2007; Ran et al., 2012). Comparison between our tropospheric $\mathrm{O}_{3}$ fields with Fig. 7 of Ziemke et al. (2011) show consistent spatial and temporal features, but the enhanced tropospheric $\mathrm{O}_{3}$ at $50^{\circ} \mathrm{N}$ during March-July ( $>42 \mathrm{DU}$ ) in the SCIAMACHY data product is not present in Fig. 7 of Ziemke et al. (2011).

\subsection{Global distribution of tropospheric ozone columns from SCIAMACHY, TES and OMI/MLS}

Global measurements of tropospheric $\mathrm{O}_{3}$ are needed to test our understanding of its sources, seasonal variations and long-range transport of air pollutants (Creilson et al., 2003, 2005). They also allow for the generation of temporally extended records that are vital for the investigation of long-term trends (Fishman et al., 2005; Kim and Newchurch, 1996; Valks et al., 2003).

Tropospheric $\mathrm{O}_{3}$ is a pollutant, exhibiting higher concentrations in summer and spring months. The tropospheric $\mathrm{O}_{3}$ seasonality is caused by variation in tropospheric background $\mathrm{O}_{3}$, temporal variation of precursor emissions $\left(\mathrm{NO}_{\mathrm{x}}\right.$, VOCs, $\mathrm{CO}, \mathrm{CO}_{2}, \mathrm{CH}_{4}$ ), systematic seasonal changes in transport meteorology as well as by the seasonality of photochemical oxidation and removal processes. Figure 14 shows the global distributions of tropospheric $\mathrm{O}_{3}$ from SCIAMACHY for four seasons: winter (DJF), summer (JJA), spring (MAM) and autumn (SON) in 2003. Significant differences between the Northern and Southern Hemispheres, as well as differences between the seasons are observed. The tropospheric $\mathrm{O}_{3}$ wave-one feature, which is persistent in the southern tropics (Chandra et al., 2003; Edwards et al., 2003; Thompson et al., 2000) is observed in JJA, MAM and SON, but not clearly present in DJF. High TOC values are observed during spring and summer. An increase in tropospheric $\mathrm{O}_{3}$ observed at the mid- and high northern latitudes might be explained by a combination of different effects, arising from 

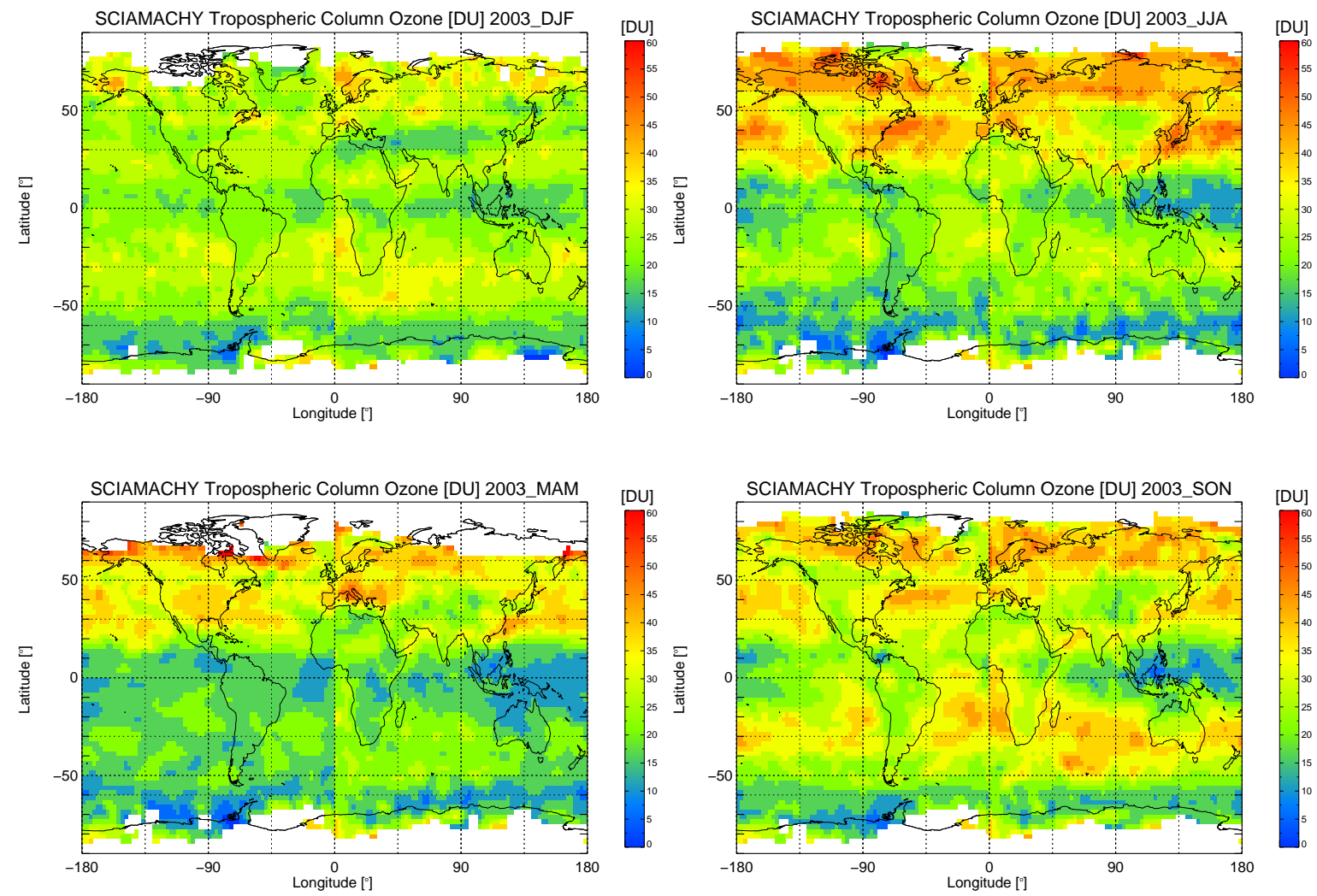

Figure 14. Tropospheric ozone distributions in Dobson units retrieved from SCIAMACHY observations for different seasons in 2003; top panels from left to right: December-January-February, and June-July-August, bottom panels from left to right: March-April-May and September-October-November.

STE, combustion of fossil fuels, biofuel and biomass burning, biogenic, and soil and oceanic emissions (e.g. Danielsen, 1968; Chandra et al., 2004; Parrington et al., 2012; Pfister et al., 2008; Stohl et al., 2007; Thompson et al., 2008). Additionally, the increase in TOCs in the northern high latitudes is most probably explained by the transport of $\mathrm{O}_{3}$ plumes from the midlatitudes to the higher latitudes (Levy II et al., 1985). The smallest TOCs are observed in the SH polar region. This is explained by the relative lack of ozone precursors, the associated low rate of ozone production, as well as by the lower influence of STE events (e.g. de Laat et al., 2005). In addition, loss of $\mathrm{O}_{3}$ following the release of halogens into the boundary layer in high latitudes during spring may also further reduce $\mathrm{O}_{3}$ (Kaleschke et al., 2004; Schönhardt et al., 2008).

In the top left panel of Fig. 14, which corresponds to boreal winter, a local maximum in SCIAMACHY TOC is observed in the southern Atlantic region, which is explained by emissions from extensive biomass burning and long-range transport of ozone and its precursors (e.g. Moxim and Levy II, 2000; Thompson et al., 2000; Fishman et al., 2003). Elevated TOCs observed over northern Atlantic and Pacific midlatitudes are explained by long-range transport of photochemically generated $\mathrm{O}_{3}$ from North America, Europe and East
Asia, as well as systematic downward transport from the stratosphere, which is associated with the strong jet stream off the east coast of Asia (e.g. Chandra et al., 2004; Stohl et al., 2003, 2007).

During boreal summer (top right panel of Fig. 14), SCIAMACHY captured plumes of high TOC of about 35-55 DU over the eastern United States, eastern Asia, the North Atlantic and North Pacific. Elevated $\mathrm{O}_{3}$ amounts over the Mediterranean region and high $\mathrm{O}_{3}$ plumes in the tropical South Atlantic are observed in accordance with previous studies (e.g. Lelieveld et al., 2002). The high values of TOC during boreal summer are explained by photochemical production of $\mathrm{O}_{3}$ from anthropogenic pollution and biogenic volatile organic compounds (VOCs) and $\mathrm{NO}_{x}$ (e.g. Chandra et al., 2004; Zhang et al., 2011). Tropospheric $\mathrm{O}_{3}$ sources such as STE, the photochemistry in air masses influenced by biomass burning and lightning also play a role during this season (Oltmans et al., 1996; Pfister et al., 2008; Ran et al., 2012; Stohl et al., 2007; Thompson et al., 2008). The lowest $\mathrm{O}_{3}$ values in this season are observed over the eastern Pacific.

In the plot in the bottom left panel of Fig. 14, which corresponds to boreal spring, high TOC values from SCIAMACHY are observed in the northern subtropics and midlatitudes. These high TOC values are considered to originate 

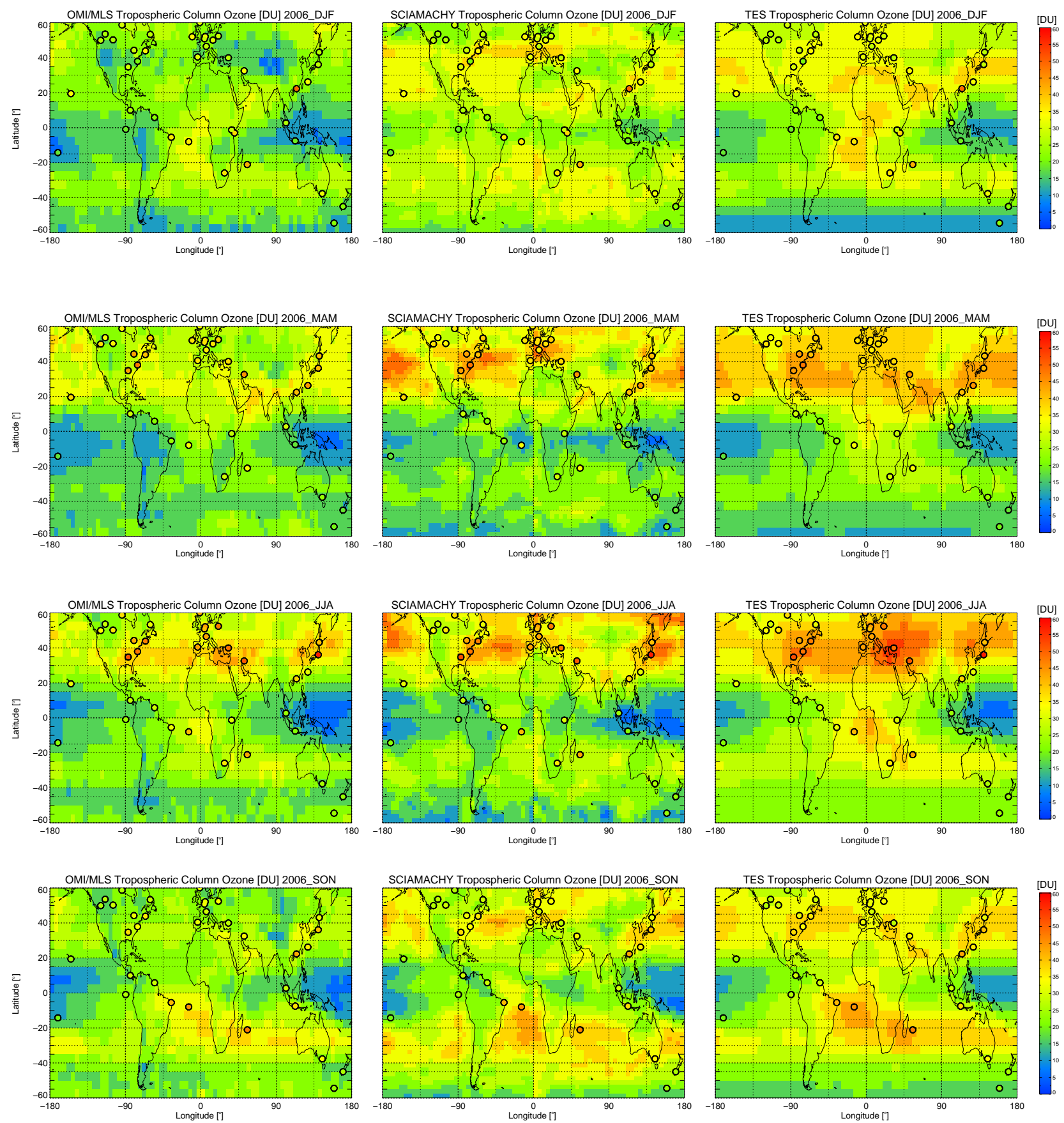

Figure 15. A comparison of the tropospheric ozone columns in Dobson units retrieved from left to right, from the measurements of OMI/MLS, SCIAMACHY and TES for different seasons in 2006; from the top row to the bottom row, the average composites are shown for December-January-February, March-April-May, June-July-August and September-October-November.

to a large part from STE processes, which have an annual maximum during spring in this zonal band (e.g. Danielsen, 1968; Chandra et al., 2004; Stohl et al., 2003; Zhang et al., 2011). Anthropogenic pollution also plays a role during this season (Stohl et al., 2007). In this season SCIAMACHY captured low TOC values over the tropical eastern Pacific, which might be due to increase in $\mathrm{HO}_{\mathrm{x}}$ concentration (Liu et al., 2005).

In the plot in the bottom right panel of Fig. 14, corresponding to boreal autumn, high TOC values from SCIAMACHY are observed over the tropical Atlantic and Pacific. The high TOC values in these regions are explained by advection of subtropical $\mathrm{O}_{3}$ rich air into the tropics, as well as by biomass 
burning, lightning, and zonal transport of $\mathrm{O}_{3}$ polluted air masses, as part of the Walker circulation (e.g. Levy II et al., 1985; Kim and Newchurch, 1998; Moxim and Levy II, 2000; Thompson et al., 2003). The high SCIAMACHY TOC values observed along the zonal band at approximately $30-40^{\circ} \mathrm{S}$ in the $\mathrm{SH}$ are similar to the high values observed at the midlatitudes in the $\mathrm{NH}$ during summer and spring. These seasonal enhancements in TOC are of dynamical origin caused by STE (de Laat et al., 2005).

To further investigate the TOCs retrieved from SCIAMACHY, we compared our results with those from TES and OMI/MLS, overlaid with TOCs from ozonesondes (filled circles). In the seasonal plots shown in Fig. 15, similar features as well as differences in regional patterns can be observed in the different satellite data sets. The differences between the satellite data result from the differences in operations of the instruments, the information content of the remote sensing data in the different spectral regions and the algorithms used in the retrievals. All three data products are from satellite instruments that have different vertical resolutions and overpass times. The a priori information as well as cloud detection and removal algorithms may also differ between instruments. Differences in tropopause criteria implemented in the various tropospheric $\mathrm{O}_{3}$ retrievals may also play a role.

\section{Summary and conclusions}

We have presented a method to derive a new tropospheric $\mathrm{O}_{3}$ column (TOC) data product by using limb-nadir matching observations of scattered solar radiation made by SCIAMACHY from 2003 to 2011. The spatial resolution of the tropospheric $\mathrm{O}_{3}$ data product, which was determined by the collocated limb and nadir resolution, is about $60 \mathrm{~km}$ (along track) $\times 240 \mathrm{~km}$ (across track). Monthly mean values have errors estimated to be less than $6 \mathrm{DU}$, which corresponds to about $20 \%$ of the TOCs.

This study provides a comprehensive assessment of the error budget, comprising the different error contributions to the retrieved TOCs. The most important error contribution is the error in the SOCs, which is estimated to be less than 5 DU or $2 \%$ of the SOC globally. The other error sources are uncertainties in the total columns and the effect of the tropopause height on the TOCs. The impact of clouds was minimized by using only limb $\mathrm{O}_{3}$ profiles and total columns that have negligible cloud contamination.

The resulting TOC data set has been compared with the TOCs determined from ozonesondes, showing a good agreement to within 3 DU. Time series plots of TOCs retrieved from SCIAMACHY and other satellite instruments are presented, showing a good agreement in capturing the seasonal variations between all instruments. However, some disagreement on the amplitude of the seasonal variations has been identified. Global maps of TOC show the expected seasonal and spatial patterns. Comparisons with TOCs retrieved from
TES and OMI/MLS show similar global morphology and seasonal variations in many regions but differences in others. In summary, the reported TOC data set retrieved by using SCIAMACHY limb-nadir matching observations provides a valuable data record from 2003 to 2012.

Acknowledgements. We thank the OMI/MLS and TES teams for providing TOC data and making it available for comparison. We also thank the groups that provided the ozonesonde data and acknowledge WOUDC for archiving and making it available for use. We thank ESA and German Aerospace DLR for providing SCIAMACHY level-1 data for this study. This work was funded in parts by the German Aerospace DLR project SADOS (FKZ 50EE1105), by ESA through the SCIAMACHY Quality Working Group, by Ernst-Moritz-Arndt-University of Greifswald and also by the University and State of Bremen, Germany. The SCIAMACHY instrument, which flew on ESA Envisat, was supported by Germany, the Netherlands and Belgium.

Edited by: P. K. Bhartia

\section{References}

Aumann, H. H., Chahine, M. T., Gautier, C., Goldberg, M. D., Kalnay, E., McMillin, L. M., Revercomb, H., Rosenkranz, P. W., Smith, W. L., Staelin, D. H., Strow, L. L., and Susskind, J.: AIRS/AMSU/HSB on the Aqua mission: Design, science objectives, data products and processing systems, IEEE T. Geosci. Remote Sens., 41, 253-264, 2003.

Balis, D., Kroon, M., Koukouli, M. E., Brinksma, E. J., Labow, G., Veefkind, J. P., and McPeters, R. D.: Validation of Ozone Monitoring Instrument total ozone column measurements using Brewer and Dobson spectrophotometer ground-based observations, J. Geophys. Res., 112, D24S46, doi:10.1029/2007JD008796, 2007.

Beer, R.: TES on the Aura mission: Scientific objectives, measurements and analysis overview, IEEE T. Geosci. Remote Sens., 44, 1102-1105, 2006.

Beer, R., Glavich, T. A., and Rider, D. M.: Tropospheric Emission Spectrometer for the Earth Observing System's Aura satellite, Appl. Optics, 40, 2356-2367, 2001.

Beirle, S., Kühl, S., Puķite, J., and Wagner, T.: Retrieval of tropospheric column densities of $\mathrm{NO}_{2}$ from combined SCIAMACHY nadir/limb measurements, Atmos. Meas. Tech., 3, 283-299, doi:10.5194/amt-3-283-2010, 2010.

Bell, M. L., McDermott, A., Zeger, S. L., Samet, J. M., and Dominici, F.: Ozone and short-term mortality in 95 US urban communities, 1987-2000, JAMA-J. Am. Med. Assoc., 292, 2372 2378, 2004.

Bhartia, P. K., McPeters, R. D., Mateer, C. L., Flynn, L. E., and Wellemeyer, C.: Algorithm for the estimation of vertical ozone profiles from the backscattered ultraviolet technique, J. Geophys. Res. Atmos., 101, 18793-18806, 1996.

Bhartia, P. K., McPeters, R. D., Flynn, L. E., Taylor, S., Kramarova, N. A., Frith, S., Fisher, B., and DeLand, M.: Solar Backscatter UV (SBUV) total ozone and profile algorithm, Atmos. Meas. Tech., 6, 2533-2548, doi:10.5194/amt-6-2533-2013, 2013. 
Bogumil, K., Orphal, J., Homann, T., Voigt, S., Spietz, P., Fleischmann, O. C., Vogel, A., Hartmann, M., Bovensmann, H., Frerick, J., and Burrows, J. P.: Measurements of molecular absorption spectra with the SCIAMACHY pre-flight model: instrument characterisation and reference data for atmospheric remote sensing in the 230-2380 nm region, J. Photochem. Photobio. A., 157, 157-167, 2003.

Bovensmann, H., Burrows, J. P., Buchwitz, M., Frerick, J., Noël, S., Rozanov, V. V., Chance, K. V., and Goede, A. P. H.: SCIAMACHY-Mission objectives and measurement modes, J. Atmos. Sci., 56, 127-150, 1999.

Bowman, K. W., Rodgers, C. D., Kulawik, S. S., Worden, J., Sarkissian, E., Osterman, G., Steck, T., Lou, M., Eldering, A., Shephard, M., Worden, H., Lampel, M., Clough, S., Brown, P., Rinsland, C., Gunson, M., and Beer, R.: Tropospheric emission spectrometer: Retrieval method and error analysis, IEEE T. Geosci. Remote, 44, 1297-1307, 2006.

Boxe, C. S., Worden, J. R., Bowman, K. W., Kulawik, S. S., Neu, J. L., Ford, W. C., Osterman, G. B., Herman, R. L., Eldering, A., Tarasick, D. W., Thompson, A. M., Doughty, D. C., Hoffmann, M. R., and Oltmans, S. J.: Validation of northern latitude Tropospheric Emission Spectrometer stare ozone profiles with ARC-IONS sondes during ARCTAS: sensitivity, bias and error analysis, Atmos. Chem. Phys., 10, 9901-9914, doi:10.5194/acp10-9901-2010, 2010.

Bracher, A., Lamsal, L. N., Weber, M., Bramstedt, K., ColdeweyEgbers, M., and Burrows, J. P.: Global satellite validation of SCIAMACHY $\mathrm{O}_{3}$ columns with GOME WFDOAS, Atmos. Chem. Phys., 5, 2357-2368, doi:10.5194/acp-5-2357-2005, 2005

Brasseur, G. P., Hauglustaine, D. A., Walters, S., Rasch, R. J., Müller, J., Granier, C., and Tie, X. X.: MOZART, a global chemical transport model for ozone and related chemical tracers 1. Model description, J. Geophys. Res., 103, 28265-28289, doi:10.1029/98JD02397, 1998.

Brewer, A., and Milford, J.: The Oxford-Kew Ozonesonde, Proc. Roy. Soc. London, Ser. A, 256, 470-495, doi:10.1098/rspa.1960.0120, 1960.

Burrows, J. P., Hölzle, E., Goede, A. P. H., Visser, H., and Fricke, W.: SCIAMACHY - Scanning Imaging Absorption Spectrometer for Atmospheric Chartography, Acta Astronaut., 35, 445-451, 1995.

Burrows, J. P., Richter, A., Dehn, A., Deters, B., Himmelmann, S., Voigt, S., and Orphal, J.: Atmospheric remote-sensing reference data from GOME-2. temperature-dependent absorption cross sections of $\mathrm{O}_{3}$ in the 231-794 nm range, J. Quant. Spectrosc. Radiat. Transfer, 61, 509-517, 1999.

Burrows, J. P., Bovensmann, H., Bergametti, G., Flaud, J. M., Orphal, J., Noël, S., Monks, P. S., Corlett, G. K., Goede, A. P. H., von Clarmann, T., Steck, T., Fischer, H., and Friedl-Vallon, F.: The geostationary tropospheric pollution explorer (GeoTROPE) missions: objects, requirements and mission concept, Adv. Space Res., 23, 682-687, 2004.

Chandra, S., Ziemke, J. R., Bhartia, P. K., and Martin, R. V.: Tropical tropospheric ozone: Implications for dynamics and biomass burning, J. Geophys. Res., 107, 4188, doi:10.1029/2001JD000447, 2002.

Chandra, S., Ziemke, J. R., and Martin, R. V.: Tropospheric ozone at tropical and middle latitudes derived from TOMS/MLS residual:
Comparison with a global model, J. Geophys. Res., 108, 4291, doi:10.1029/2002JD002912, 2003.

Chandra, S., Ziemke, J. R., Tie, X., and Brasseur, G.: Elevated ozone in the troposphere over the Atlantic and Pacific oceans in the Northern Hemisphere, Geophys. Res. Lett., 31, L23102, doi:10.1029/2004GL020821, 2004.

Coldewey-Egbers, M., Weber, M., Lamsal, L. N., de Beek, R., Buchwitz, M., and Burrows, J. P.: Total ozone retrieval from GOME UV spectral data using the weighting function DOAS approach, Atmos. Chem. Phys., 5, 1015-1025, doi:10.5194/acp5-1015-2005, 2005.

Creilson, J. K., Fishman, J., and Wozniak, A. E.: Intercontinental transport of tropospheric ozone: a study of its seasonal variability across the North Atlantic utilizing tropospheric ozone residuals and its relationship to the North Atlantic Oscillation, Atmos. Chem. Phys., 3, 2053-2066, doi:10.5194/acp-3-2053-2003, 2003.

Creilson, J. K, Fishman, J., and Wozniak, A. E.: Arctic Oscillationinduced variability in satellite-derived tropospheric ozone, Geophys. Res. Lett., 32, L14822, doi:10.1029/2005GL023016, 2005.

Cuesta, J., Eremenko, M., Liu, X., Dufour, G., Cai, Z., Höpfner, M., von Clarmann, T., Sellitto, P., Foret, G., Gaubert, B., Beekmann, M., Orphal, J., Chance, K., Spurr, R., and Flaud, J.-M.: Satellite observation of lowermost tropospheric ozone by multispectral synergism of IASI thermal infrared and GOME-2 ultraviolet measurements over Europe, Atmos. Chem. Phys., 13, 9675-9693, doi:10.5194/acp-13-9675-2013, 2013.

Danielsen, E. F.: Stratospheric-Tropospheric Exchange Based on Radioactivity, Ozone and Potential Vorticity, J. Atmos. Sci., 25, 502-518, 1968.

de Laat, A. T. J., Aben, I., and Roelofs, G. J.: A model perspective on total tropospheric $\mathrm{O}_{3}$ column variability and implications for satellite observations, J. Geophys. Res., 110, D13303, doi:10.1029/2004JD005264, 2005.

Di Noia, A., Sellitto, P., Del Frate, F., and de Laat, J.: Global tropospheric ozone column retrievals from OMI data by means of neural networks, Atmos. Meas. Tech., 6, 895-915, doi:10.5194/amt6-895-2013, 2013.

Ebi, K. and McGregor, G.: Climate change, tropospheric ozone and particulate matter, and health impacts, Environ. Health Perspect. 116, 1449-1455, 2008.

Edwards, D. P., Lamarque, J. -F., Attié, J. -L., Emmons, L. K., Richter, A., Cammas, J. -P., Gille, J. C., Francis, G. L., Deeter, M. N., Warner, J., Ziskin, D. C., Lyjak, L. V., Drummond, J. R., and Burrows, J. P.: Tropospheric ozone over the tropical Atlantic: A satellite perspective, J. Geophys. Res., 108, 4237, doi:10.1029/2002JD002927, 2003.

Eichmann K. U., von Savigny, C., Reichl, P., Robert, C., Steinwagner, J., Bovensmann, H., and Burrows, J. P.: SCODA, SCIAMACHY ClOud Detection Algorithm from limb radiance measurements Algorithm Theoretical Baseline Document (ATBD), Institute of Environmental Physics, University of Bremen, 2009.

Eldering, A., Kulawik, S. S., Worden, J. R., Bowman, K. W., and Osterman, G. B.: Implementation of cloud retrievals for Tropospheric Emission Spectrometer atmospheric retrievals: 2. Characterization of cloud top pressures and effective optical depth retrievals, J. Geophys. Res., 113, D16S37, doi:10.1029/2007JD008858, 2008. 
Fishman, J. and Balok, A. E.: Calculation of daily tropospheric ozone residuals using TOMS and empirically improved SBUV measurements: Application to an ozone pollution episode over the eastern United States, J. Geophys. Res., 104, 30319-30340, 1999.

Fishman, J. and Larsen, J. C.: Distribution of total ozone and stratospheric ozone in the tropics: Implications for the distribution of tropospheric ozone, J. Geophys. Res., 92, 6627-6634, doi:10.1029/JD092iD06p06627, 1987.

Fishman, J., Watson, C., Larsen, J., and Logan, J.: Distribution of tropospheric ozone determined from satellite data, J. Geophys. Res., 95, 3599-3617, doi:10.1029/JD095iD04p03599, 1990.

Fishman, J., Wozniak, A. E., and Creilson, J. K.: Global distribution of tropospheric ozone from satellite measurements using the empirically corrected tropospheric ozone residual technique: Identification of the regional aspects of air pollution, Atmos. Chem. Phys., 3, 893-907, doi:10.5194/acp-3-893-2003, 2003.

Fishman, J., Creilson, J. K., Wozniak, A. E., and Crutzen, P. J.: Interannual variability of stratospheric and tropospheric ozone determined from satellite measurements., J. Geophys. Res., 110, D20306, doi:10.1029/2005JD005868, 2005.

Flittner, D. E., Bhartia, P. K., and Herman, B. M.: $\mathrm{O}_{3}$ profiles retrieved from limb scatter measurements: Theory, Geophys. Res. Lett., 27, 2601-2604, 2000.

Froidevaux, L., Livesey, N. J., Read, W. G., Jiang, Y. B., Jimenez, C., Filipiak, M. J., Schwartz, M. J., Santee, M. L., Pumphrey, H. C., Jiang, J. H., Wu, D. L., Manney, G. L., Drouin, B. J., Waters, J. W., Fetzer, E. J., Bernath, P. F., Boone, C. D., Walker, K. A., Jucks, K. W., Toon, G. C., Margitan, J. J., Sen, B., Webster, C. R., Christensen, L. E., Elkins, J. W., Atlas, E., Lueb, R. A., and Hendershot, R.: Early validation analyses of atmospheric profiles from EOS MLS on the aura Satellite, IEEE Trans. Geophys. Remote Sens., 44(5), 1106 - 1121, doi:10.1109/TGRS.2006.864366, 2006.

Froidevaux, L., Jiang, Y. B., Lambert, A., Livesey, N. J., Read, W. G., Waters, J. W., Browell, E. V., Hair, J. W., Avery, M. A., McGee, T. J., Twigg, L. W., Sumnicht, G. K., Jucks, K. W., Margitan, J. J., Sen, B., Stachnik, R. A., Toon, G. C., Bernath, P. F., Boone, C. D., Walker, K. A., Filipiak, M. J., Harwood, R. S., Fuller, R. A., Manney, G. L., Schwartz, M. J., Daffer, W. H., Drouin, B. J., Cofield, R. E., Cuddy, D. T., Jarnot, R. F., Knosp, B. W., Perun, V. S., Snyder, W. V., Stek, P. C., Thurstans, R. P., and Wagner, P. A.: Validation of Aura Microwave Limb Sounder stratospheric ozone measurements, J. Geophys. Res., 113, D15, doi:10.1029/2007JD008771, 2008.

Fuhrer, J. and Booker, F.: Ecological issues related to ozone: Agricultural issues, Environ. Int., 29, 141-154, 2003.

Fussen, D. and Bingen, C.: A volcanism dependent model for the extinction profile of stratospheric aerosols in the UV-visible range, Geophys. Res. Lett., 26, 703-706, 1999.

Gottwald, M., and Bovensmann, H. (Eds.): SCIAMACHY - Exploring the Changing Earth's Atmosphere, 1st Edn., ISBN 97890-481-9895-5, springer, doi:10.1007/978-90-481-9896-2, 2011.

Hilboll, A., Richter, A., Rozanov, A., Hodnebrog, Ø., Heckel, A., Solberg, S., Stordal, F., and Burrows, J. P.: Improvements to the retrieval of tropospheric $\mathrm{NO}_{2}$ from satellite - stratospheric correction using SCIAMACHY limb/nadir matching and comparison to Oslo CTM2 simulations, Atmos. Meas. Tech., 6, 565-584, doi:10.5194/amt-6-565-2013, 2013.
Hoinka, K. P.: Statistics of the global tropopause pressure, Mon. Weather Rev., 126, 3303-3325, 1998.

Holton, J. R., Haynes, P. H., McIntyre, M. E., Douglass, A. R., Rood, R. B., and Pfister, L.: Stratosphere-troposphere exchange, Rev. Geophys., 33, 403-439, doi:10.1029/95RG02097, 1995.

Hoogen, R., Rozanov, V. V., Bramstedt, K., Eichmann, K. U., Weber, M., deBeek, R., Buchwitz, M., and Burrows, J. P.: Height resolved ozone information from GOME data, Earth Observation Quarterly, 58, 9-10, 1998.

Hoogen, R., Rozanov, V. V., and Burrows, J. P.: Ozone profiles from GOME satellite data: algorithm description and first validation, J. Geophys. Res., 104, 8263-8280, 1999.

Jacobson, M. Z.: Air Pollution and Global Warming: History, Science, and Solutions, 2nd Edn., Cambridge Univ. Press, Cambridge, 2012.

Jourdain, L., Worden, H. M., Bowman, K., Li, Q. B., Eldering, A., Kulawik, S. S., Osterman, G., Boersma, K. F., Fisher, B., Rinsland, C. P., Beer, R., and Gunson, M.: Tropospheric vertical distribution of tropical Atlantic ozone observed by TES during the northern African biomass burning season, Geophys. Res. Lett., 34, L04810, doi:10.1029/2006GL028284, 2007.

Kaleschke, L., Richter, A., Burrows, J., Afe, O., Heygster, G., Notholt, J., Rankin, A. M., Roscoe, H. K., Hollwedel, J., Wagner, T., and Jacobi, H. -W.: Frost flowers on sea ice as a source of sea salt and their influence on tropospheric halogen chemistry, Geophys. Res. Lett., 31, L16114, doi:10.1029/2004GL020655, 2004.

Kim, J. H. and Newchurch, M. J.: Climatology and trends of tropospheric ozone over the eastern Pacific Ocean: The influences of biomass burning and tropospheric dynamics, Geophys. Res. Lett., 23, 3723-3726, doi:10.1029/96GL03615, 1996.

Kim, J. H. and Newchurch, M. J.: Biomass-burning influence on tropospheric ozone over New Guinea and South America, J. Geophys. Res., 103, 1455-1461, doi:10.1029/97JD02294, 1998.

Kim, J. H., Newchurch, M. J., and Kunhee, H.: Distribution of Tropical Tropospheric Ozone Determined by the Scan-Angle Method Applied to TOMS Measurements, J. Atmos. Sci., 58, 2699-2708, 2001.

Kobayashi, J. and Toyama, Y.: On various methods of measuring the vertical distribution of atmospheric ozone (III) - Carbon iodine type chemical ozonesonde, Pap. Met. Geophys., 17, 113126, 1966.

Koelemeijer, R. and Stammes, P.: Effects of clouds on ozone column retrieval from GOME UV measurements, J. Geophys. Res., 104, 8281-8294, 1999.

Kokhanovsky, A. A. and Rozanov, V. V.: The physical parameterization of the top-of-atmosphere reflection function for a cloudy atmosphere underlying surface system: the oxygen A-band case study, J. Quant. Spectr. Rad. Transfer, 85, 35-55, 2004.

Komhyr, W. D.: Electrochemical concentration cells for gas analysis, Ann. Geophys., 25, 203-210, 1969,

http://www.ann-geophys.net/25/203/1969/.

Kulawik, S. S., Worden, J., Eldering, A., Bowman, K., Gunson, M., Osterman, G. B., Zhang, L., Clough, S., Shephard, M. W., and Beer, R.: Implementation of cloud retrievals for Tropospheric Emission Spectrometer (TES) atmospheric retrievals: part 1. Description and characterization of errors on trace gas retrievals, J. Geophys. Res., 111, D24204, doi:10.1029/2005JD006733, 2006. 
Ladstätter-Weißenmayer, A., Meyer-Arnek, J., Schlemm, A., and Burrows, J. P.: Influence of stratospheric airmasses on tropospheric vertical $\mathrm{O}_{3}$ columns based on GOME (Global Ozone Monitoring Experiment) measurements and backtrajectory calculation over the Pacific, Atmos. Chem. Phys., 4, 903-909, doi:10.5194/acp-4-903-2004, 2004.

Lelieveld, J., Berresheim, H., Borrmann, S., Crutzen, P. J., Dentener, F. J., Fischer, H., Feichter, J., Flatau, P. J., Heland, J., Holzinger, R., Korrmann, R., Lawrence, M. G., Levin, Z., Markowicz, K. M., Mihalopoulos, N., Minikin, A., Ramanathan, V., de Reus, M., Roelofs, G. J., Scheeren, H. A., Sciare, J., Schlager, H., Schultz, M., Siegmund, P., Steil, B., Stephanou, E. G., Stier, P., Traub, M., Warneke, C., Williams, J., and Ziereis, H.: Global air pollution crossroads over the Mediterranean, Science, 298, 794-799, doi:10.1126/science.1075457, 2002.

Levelt, P. F., van den Oord, G. H. J., Dobber, M. R., Mälkki, A., Visser, H., de Vries, J., Stammes, P., Lundell, J. O. V., and Saari, H.: The Ozone Monitoring Instrument, IEEE T. Geosci. Remote Sens., 44, 1093-1101, 2006.

Levy II, H., Mahlman, J. D., Moxim, W. J., and Liu, S. C.: Tropospheric ozone: The role of transport, J. Geophys. Res., 90, 37533772, 1985.

Lippmann, M.: Health-effects of tropospheric ozone, Environ. Sci. Technol., 25, 1954-1962, 1991.

Liu, X., Chance, K., Sioris, C. E., Spurr, R. J. D., Kurosu, T. P., Martin, R. V., and Newchurch, M. J.: Ozone profile and tropospheric ozone retrievals from the Global Ozone Monitoring Experiment: Algorithm description and validation, J. Geophys. Res., 110, D20307, doi:10.1029/2005JD006240, 2005.

Liu, X., Chance, K., Sioris, C. E., Kurosu, T. P., Spurr, R. J. D., Martin, R. V., Fu, T. M., Logan, J. A., Jacob, D. J., Palmer, P. I., Newchurch, M. J., Megretskaia, I. A., and Chatfield, R.: First directly retrieved global distribution of tropospheric column ozone from GOME: Comparison with the GEOS-CHEM model, J. Geophys. Res., 111, D02308, doi:10.1029/2005JD006564, 2006.

Liu, X., Bhartia, P. K., Chance, K., Spurr, R. J. D., and Kurosu, T. P.: Ozone profile retrievals from the Ozone Monitoring Instrument, Atmos. Chem. Phys., 10, 2521-2537, doi:10.5194/acp-10-25212010, 2010.

Livesey, N. J., Read, W. G., Froidevaux, L., Lambert, A., Manney, G. L., Pumphrey, H. C., Santee, M. L., Schwartz, M. J., Wang, S., Cofield, R. E., Cuddy, D. T., Fuller, R. A., Jarnot, R. F., Jiang, J. H., Knosp, B. W., Stek, P. C., Wagner, P. A., and Wu, D. L.: EOS MLS Version 3.3 Level 2 data quality and description document, Tech. rep., Jet Propulsion Laboratory, http://mls.jpl. nasa.gov/data/v3-3_data_quality_document.pdf, last access: 12 December 2013, 2011.

Logan, J. A.: Tropospheric ozone: Seasonal behavior, trends, and anthropogenic influence, J. Geophys Res., 90, 10463-10482, 1985.

Logan, J. A., Staehelin, J., Megretskaia, I. A., Cammas, J. -P., Thouret, V., Claude, H., De Backer, H., Steinbacher, M., Scheel, H. -E., Stübi, R., Fröhlich, M., and Derwent, R.: Changes in ozone over Europe: Analysis of ozone measurements from sondes, regular aircraft (MOZAIC) and alpine surface sites, J. Geophys. Res., 117, D09301, doi:10.1029/2011JD016952, 2012.

Martin, R. V., Jacob, D. J., Logan, J. A., Bey, I., Yantosca, R. M., Staudt, A. C., Li, Q., Fiore, A. M., Duncan, B. N., Liu, H., Ginoux, P., and Thouret, V.: Interpretation of TOMS ob- servations of tropical tropospheric ozone with a global model and in situ observations, J. Geophys. Res., 107(D18), 4351, doi:10.1029/2001JD001480, 2002.

Matthews, E.: Vegetation, Land-Use and Seasonal Albedo Data Sets: In Global Change Data Base Africa Documentation, Appendix D, NOAA/NGDC, 1984.

Mieruch, S., Weber, M., von Savigny, C., Rozanov, A., Bovensmann, H., Burrows, J. P., Bernath, P. F., Boone, C. D., Froidevaux, L., Gordley, L. L., Mlynczak, M. G., Russell III, J. M., Thomason, L. W., Walker, K. A., and Zawodny, J. M.: Global and long-term comparison of SCIAMACHY limb ozone profiles with correlative satellite data (2002-2008), Atmos. Meas. Tech., 5, 771-788, doi:10.5194/amt-5-771-2012, 2012.

Moxim, W. J. and Levy II, H.: A model analysis of the tropical South Atlantic Ocean tropospheric ozone maximum: The interaction of transport and chemistry, J. Geophys. Res., 105, 1739317415, 2000.

Müller, M. D., Kaifel, A. K., Weber, M., Tellmann, S., Burrows, J. P., and Loyola, D.: Ozone profile retrieval from Global Ozone Monitoring Experiment (GOME) data using a neural network approach (Neural Network Ozone Retrieval System (NNORSY)), J. Geophys. Res., 108, 4497, doi:10.1029/2002JD002784, D16, 2003.

Munro, R., Siddans, R., Reburn, W. J., and Kerridge, B. J.: Direct measurement of tropospheric ozone from space, Nature, 392, 168-171, doi:10.1038/32392, 1998.

Nassar, R., Logan, J. A., Worden, H. M., Megretskaia, I. A., Bowman, K. W., Osterman, G. B., Thompson, A. M., Tarasick, D. W., Austin, S., Claude, H., Dubey, M. K., Hocking, W. K., Johnson, B. J., Joseph, E., Merrill, J., Morris, G. A., Newchurch, M., Oltmans, S. J., Posny, F., Schmidlin, F. J., Vömel, H., Whiteman, D. N., and Witte, J. C.: Validation of Tropospheric Emission Spectrometer (TES) nadir ozone profiles using ozonesonde measurements, J. Geophys. Res., 113, D15S17, doi:10.1029/2007JD008819, 2008.

Natraj, V., Liu, X., Kulawik, S. S., Chance, K., Chatfield, R., Edwards, D. P., Eldering, A., Francis, G., Kurosu, T., Pickering, K., Spurr, R., and Worden, H.: Multispectral sensitivity studies for the retrieval of tropospheric and lowermost tropospheric ozone from simulated clear sky GEO-CAPE measurements, Atmos. Environ., 45, 7151-7165, doi:10.1016/j.atmosenv.2011.09.014, 2011.

Newchurch, M. J., Liu, X., Kim, J. H., and Bhartia, P. K.: On the accuracy of total ozone mapping spectrometer retrievals over tropical cloudy regions, J. Geophys. Res., 106, 32315-32326, 2001.

Oltmans, S., Levy II, H., Harris, J., Merrill, J., Moody, J., Lathrop, J., Cuevas, E., Trainer, M., O’Neill, M., Prospero, J., Vömel, H., and Johnson, B.: Summer and spring ozone profiles over the North Atlantic from ozonesonde measurements, J. Geophys. Res., 101, 29179-29200, 1996.

Osterman, G., Bowman, K., Eldering, A., Fisher, B., Herman, R., Jacob, D., Jourdain, L., Kulawik, S., Luo, M., Monarrez, R., Osterman, G., Paradise, S., Richards, N., Rider, D., Shepard, D., Worden, H., Worden, J., and Yun, H.: Tropospheric Emission Spectrometer TES L2 Data User's Guide (up to \& including version F03-03 data), Version 2.00, June 1, 2006, Jet Propul. Lab., Calif. Inst. Of Technol., Pasadena, Calif., 2006.

Osterman, G., Kulawik, S. S., Worden, H. M., Richards, N. A. D., Fisher, B. M., Eldering, A., Shephard, M. W., Froidevaux, 
L., Labow, G., Luo, M., Herman, R. L., Bowman, K. W. and Thompson, A. M.: Validation of Tropospheric Emission Spectrometer (TES) Measurements of the Total, Stratospheric and Tropospheric Column Abundance of Ozone, J. Geophys. Res., 113, D15S16, doi:10.1029/2007JD008801, 2008.

Parrington, M., Palmer, P. I., Henze, D. K., Tarasick, D. W., Hyer, E. J., Owen, R. C., Helmig, D., Clerbaux, C., Bowman, K. W., Deeter, M. N., Barratt, E. M., Coheur, P.-F., Hurtmans, D., Jiang, Z., George, M., and Worden, J. R.: The influence of boreal biomass burning emissions on the distribution of tropospheric ozone over North America and the North Atlantic during 2010, Atmos. Chem. Phys., 12, 2077—2098, doi:10.5194/acp12-2077-2012, 2012.

Pfister, G. G., Emmons, L. K., Hess, P. G., Lamarque, J. F., Thompson, A. M., and Yorks, J. E.: Analysis of the summer 2004 ozone budget over North America using IONS observations and MOZART'4 simulations, J. Geophys. Res., 113, D23306, doi:10.1029/2008JD010190, 2008.

Rahpoe, N., von Savigny, C., Weber, M., Rozanov, A. V., Bovensmann, H., and Burrows, J. P.: Error budget analysis of SCIAMACHY limb ozone profile retrievals using the SCIATRAN model, Atmos. Meas. Tech., 6, 2825-2837, doi:10.5194/amt-62825-2013, 2013.

Ran, L., Zhao, C. S., Xu, W. Y., Han, M., Lu, X. Q., Han, S. Q., Lin, W. L., Xu, X. B., Gao, W., Yu, Q., Geng, F. H., Ma, N., Deng, Z. Z., and Chen, J.: Ozone production in summer in the megacities of Tianjin and Shanghai, China: a comparative study, Atmos. Chem. Phys., 12, 7531-7542, doi:10.5194/acp-12-75312012, 2012.

Rodgers, C. D.: Inverse Methods for Atmospheric Sounding: Theory and Practice, World Sci. Pub., Singapore, ISBN 978-981-022740-1, 2000.

Rohen, G. J.: Retrieval of Upper Stratospheric and Lower Mesospheric Ozone Profiles from SCIAMACHY Limb Scatter Measurements and Observations of the Ozone Depletion During the Solar Proton Event in October and November 2003, Logos Publication, Berlin, PhD. thesis, ISBN 978-3-3825-1363-4, 2006.

Rozanov, V. V., Rozanov, A. V., Kokhanonvsky, A. A., and Burrows, J. P.: Radiative transfer through terrestrial atmosphere and ocean: Software package SCIATRAN, Quant. Spec. and Rad. Trans., 133, 13-71, doi:10.1016/j.jqsrt.2013.07.004, 2014.

Schoeberl, M. R., Ziemke, J. R., Bojkov, B., Livesey, N., Duncan, B., Strahan, S., Froidevaux, L., Kulawik, S., Bhartia, P. K., Chandra, S., Levelt, P. F., Witte, J. C., Thompson, A. M., Cuevas, E., Redondas, A., Tarasick, D. W., Davies, J., Bodeker, G., Hansen, G., Johnson, B. J., Oltmans, S. J., Vömel, H., Allaart, M., Kelder, H., Newchurch, M., Godin-Beekmann, S., Ancellet, G., Claude, H., Andersen, S. B., Kyrö, E., Parrondos, M., Yela, M., Zablocki, G., Moore, D., Dier, H., von der Gathen, P., Viatte, P., Stübi, R., Calpini, B., Skrivankova, P., Dorokhov, V., de Backer, H., Schmidlin, F. J., Coetzee, G., Fujiwara, M., Thouret, V., Posny, F., Morris, G., Merrill, J., Leong, C. P., Koenig-Langlo, G., and Joseph, E.: A trajectory-based estimate of the tropospheric ozone column using the residual method, J. Geophys. Res., 112, D24S49, doi:10.1029/2007JD008773, 2007.

Schönhardt, A., Richter, A., Wittrock, F., Kirk, H., Oetjen, H., Roscoe, H. K., and Burrows, J. P.: Observations of iodine monoxide columns from satellite, Atmos. Chem. Phys., 8, 637-653, doi:10.5194/acp-8-637-2008, 2008.
Sellitto, P., Bojkov, B. R., Liu, X., Chance, K., and Del Frate, F.: Tropospheric ozone column retrieval at northern mid-latitudes from the Ozone Monitoring Instrument by means of a neural network algorithm, Atmos. Meas. Tech., 4, 2375-2388, doi:10.5194/amt-4-2375-2011, 2011.

Sierk, B., Richter, A., Rozanov, A., von Savigny, C., Schmoltner, A. M., Buchwitz, M., Bovensmann, H., and Burrows, J. P.: Retrieval and Monitoring of Atmospheric Trace Gas Concentrations in Nadir and Limb Geometry using the Space-Borne SCIAMACHY Instrument, Environ. Monitor. Assess., 120, 65-77, doi:10.1007/s10661-005-9049-9, 2006.

Singer, S. F. and Wentworth, R. C.: A method for the determination of the vertical ozone distribution from a satellite, J. Geophys. Res., 62, 299-308, doi:10.1029/JZ062i002p00299, 1957.

Sioris, C. E., Kurosu, T. P., Martin, R. V., and Chance K.: Stratospheric and tropospheric $\mathrm{NO}_{2}$ observed by SCIAMACHY: First results, Adv. Space Res., 34, 780-785, 2004.

Sonkaew, T., Rozanov, V. V., von Savigny, C., Rozanov, A., Bovensmann, H., and Burrows, J. P.: Cloud sensitivity studies for stratospheric and lower mesospheric ozone profile retrievals from measurements of limb-scattered solar radiation, Atmos. Meas. Tech., 2, 653-678, doi:10.5194/amt-2-653-2009, 2009.

Stevenson, D. S., Dentener, F. J., Schultz, M. G., Ellingsen, K., van Noije, T. P. C., Wild, O., Zeng, G., Amann, M., Atherton, C. S., Bell, N., Bergmann, D. J., Bey, I., Butler, T., Cofala, J., Collins, W. J., Derwent, R. G., Doherty, R. M., Drevet, J., Eskes, H. J., Fiore, A. M., Gauss, M., Hauglustaine, D. A., Horowitz, L. W., Isaksen, I. S. A., Krol, M. C., Lamarque, J. -F., Lawrence, M. G., Montanaro, V., Müller, J. -F., Pitari, G., Prather, M. J., Pyle, J. A., Rast, S., Rodriguez, J. M., Sanderson, M. G., Savage, N. H., Shindell, D. T., Strahan, S. E., Sudo, K., and Szopa, S.: Multimodel ensemble simulations of presentday and near-future tropospheric ozone, J. Geophys. Res., 111, D08301, doi:10.1029/2005JD006338, 2006.

Stohl, A., Bonasoni, P., Cristofanelli, P., Collins, W., Feichter, J., Frank, A., Forster, C., Gerasopoulos, E., Gaggeler, H., James, P., Kentarchos, T., Kromp-Kolb, H., Kruger, B., Land, C., Meloen, J., Papayannis, A., Priller, A., Seibert, P., Sprenger, M. J., Roelofs, G. J., Scheel, H. E., Schnabel, C., Siegmund, P., Tobler, L., Trickl, T., Wernli, H., Wirth, V., Zanis, P., and Zerefos, C.: Stratosphere-troposphere exchange: A review, and what we have learned from STACCATO, J. Geophys. Res., 108, 8516, doi:10.1029/2002JD002490, 2003.

Stohl, A., Forster, C., Huntrieser, H., Mannstein, H., McMillan, W. W., Petzold, A., Schlager, H., and Weinzierl, B.: Aircraft measurements over Europe of an air pollution plume from Southeast Asia - aerosol and chemical characterization, Atmos. Chem. Phys., 7, 913-937, doi:10.5194/acp-7-913-2007, 2007.

Stübi, R., Levrat, G., Hoegger, B., Viatte, P., Staehelin, J., and Schmidlin, F. J.: In-flight comparison of Brewer-Mast and electrochemical concentration cell ozonesondes, J. Geophys. Res., 113, D13302, doi:10.1029/2007JD009091, 2008.

Tang, Q. and Prather, M. J.: Tropospheric column ozone: matching individual profiles from Aura OMI and TES with a chemistry-transport model, Atmos. Chem. Phys., 12, 1044110452, doi:10.5194/acp-12-10441-2012, 2012.

Thompson, A. M. and Hudson R. D.: Tropical tropospheric ozone (TTO) maps from Nimbus 7 and Earth Probe TOMS by the modified-residual method: Evaluation with sondes, ENSO sig- 
nals, and trends from Atlantic regional time series, J. Geophys. Res., 104, 26961-26975, doi:10.1029/1999JD900470, 1999.

Thompson, A. M., Doddridge, B. G., Witte, J. C., Hudson, R. D. Luke, W. T., Johnson, J. E., Johnson, B. J., Oltmans, S. J., and Weller, R.: A Tropical Atlantic Paradox: Shipboard and Satellite Views of a Tropospheric Ozone Maximum and Wave-one in January-February 1999, Geophys. Res. Lett., 27, 3317-3320, 2000.

Thompson, A. M., Witte, J. C., McPeters, R. D., Oltmans, S. J., Schmidlin, F. J., Logan, J. A., Fujiwara, M., Kirchhoff, V. W. J. H., Posny, F., Coetzee, G. J. R., Hoegger, B., Kawakami, S., Ogawa, T., Johnson, B. J., Vomel H., and Labow, G. J.: Southern Hemisphere Additional Ozonesondes (SHADOZ) 1998-2000 tropical ozone climatology: 1. Comparison with Total Ozone Mapping Spectrometer (TOMS) and ground-based measurements, J. Geophys. Res., 108, 8238, doi:10.1029/2001JD000967, 2003.

Thompson, A. M., Stone, J. B., Witte, J. C., Miller, S. K., Pierce, R. B., Chatfield, R. B., Oltmans, S. J., Cooper, O. R., Loucks, A. L., Taubman, B. F., Johnson, B. J., Joseph, E., Kucsera, T. L., Merrill, J. T., Morris, G. A., Hersey, S., Forbes, G., Newchurch, M. J., Schmidlin, F. J., Tarasick, D. W., Thouret, V., and Cammas, J. P.: Intercontinental Chemical Transport Experiment Ozonesonde Network Study (IONS) 2004: 1. Summertime upper troposphere/lower stratosphere ozone over northeastern North America, J. Geophys. Res., 112, D12S12, doi:10.1029/2006JD007441, 2007.

Thompson, A. M., Yorks, J. E., Miller, S. K., Witte, J. C., Dougherty, K. M., Morris, G. A., Baumgardner, D., Ladino, L., and Rappenglück, B.: Tropospheric ozone sources and wave activity over Mexico City and Houston during MILAGRO/Intercontinental Transport Experiment (INTEX-B) Ozonesonde Network Study, 2006 (IONS-06), Atmos. Chem. Phys., 8, 5113-5125, doi:10.5194/acp-8-5113-2008, 2008.

Toohey, M., Hegglin, M. I., Tegtmeier, S., Anderson, J., Añel, J. A., Bourassa, A., Brohede, S., Degenstein, D., Froidevaux, L., Fuller, R., Funke, B., Gille, J., Jones, A., Kasai, Y., Krüger, K., Kyrölä, E., Neu, J. L., Rozanov, A., Smith, L., Urban, J., von Clarmann, T., Walker, K. A., and Wang, R. H. J.: Characterizing sampling biases in the trace gas climatologies of the SPARC Data Initiative, J. Geophys. Res. Atmos., 118, 11847 - 11862, doi:10.1002/jgrd.50874, 2013.

Valks, P., Koelemeijer, R. B. A., van Weele, M., van Velthoven, P., Fortuin, J. P. F., and Kelder, H.: Variability in tropical tropospheric ozone: Analysis with Global Ozone Monitoring Experiment observations and a global model., J. Geophys. Res., 108, 4328, doi:10.1029/2002JD002894, 2003.

von Savigny, C., Haley, C. S., Sioris, C. E., McDade, I. C., Llewellyn, E. J., Degenstein, D., Evans, W. F. J., Gattinger, R. L., Griffioen, E., Kyrölä, E., Lloyd, N. D., McConnell, J. C., McLinden, C. A., Mégie, G., Murtagh, D. P., Solheim, B., and Strong, K.: Stratospheric ozone profiles retrieved from limb scattered sunlight radiance spectra measured by the OSIRIS instrument on the Odin satellite, Geophys. Res. Lett., 30, 1755, doi:10.1029/2002GL016401, 14, 2003.

Vountas, M., Dinter, T., Bracher, A., Burrows, J. P., and Sierk, B.: Spectral studies of ocean water with space-borne sensor SCIAMACHY using Differential Optical Absorption Spectroscopy
(DOAS), Ocean Sci., 3, 429-440, doi:10.5194/os-3-429-2007, 2007.

Waters, J. W., Froidevaux, L., Harwood, R. S., Jarnot, R. F., Pickett, H. M., Read, W. G., Siegel, P. H., Cofield, R. E., Filipiak, M. J., Flower, D. A., Holden, J. R., Lau, G. K., Livesey, N. J., Manney, G. L., Pumphrey, H. C., Santee, M. L., Wu, D. L., Cuddy, D. T., Lay, R. R., Loo, M. S., Perun, V. S., Schwartz, M. J., Stek, P. C., Thurstans, R. P., Boyles, M. A., Chandra, K. M., Chavez, M. C., Gun-Shing C., Chudasama, B. V., Dodge, R., Fuller, R. A., Girard, M. A., Jiang, J. H., Yibo J., Knosp, B. W., LaBelle, R. C., Lam, J. C., Lee, K. A., Miller, D., Oswald, J. E., Patel, N. C., Pukala, D. M., Quintero, O., Scaff, D. M., Van Snyder, W., Tope, M. C., Wagner, P. A., and Walch, M. J.: The Earth Observing System Microwave Limb Sounder (EOS MLS) on the Aura satellite, IEEE Trans. Geosci. Remote Sens., 44(5), 1075 1092, 2006.

Weber, M., Lamsal, L. N., Coldewey-Egbers, M., Bramstedt, K., and Burrows, J. P.: Pole-to-pole validation of GOME WFDOAS total ozone with groundbased data, Atmos. Chem. Phys., 5, 1341-1355, doi:10.5194/acp-5-1341-2005, 2005.

Weber, M., Lamsal, L. N., and Burrows, J. P.: Improved SCIAMACHY WFDOAS total ozone retrieval: Steps towards homogenising long-term total ozone datasets from GOME, SCIAMACHY, and GOME2, Proc. Envisat Symposium 2007, Montreux, Switzerland, 23-27 April 2007, ESA SP-636, 2007.

Weber, M., Dikty, S., Burrows, J. P., Garny, H., Dameris, M., Kubin, A., Abalichin, J., and Langematz, U.: The Brewer-Dobson circulation and total ozone from seasonal to decadal time scales, Atmos. Chem. Phys., 11, 11221-11235, doi:10.5194/acp-1111221-2011, 2011.

Weber, M., Chehade, W., Fioletov, V. E., Frith, S. M., Long, C. S., Steinbrecht, W., and Wild, J. D.: Stratospheric Ozone, in State of the Climate in 2012, Bull. Amer. Meteor. Soc., 94, S36-S37, 2013.

Wernli, H., and Bourqui, M.: A Lagrangian "1-year climatology" of (deep) cross-tropopause exchange in the extratropical Northern Hemisphere, J. Geophys. Res., 107(D2), doi:10.1029/2001JD000812, 2002.

WMO: Meteorology - A three-dimensional science: Second session of the commission for aerology, WMO Bull., IV4, 134-138, 1957.

Worden, J., Liu, X., Bowman, K., Chance, K., Beer, R., Eldering, A., Gunson, M., and Worden, H.: Improved tropospheric ozone profile retrievals using OMI and TES radiances, Geophys. Res. Lett., 34, L01809, doi:10.1029/2006GL027806, 2007.

WOUDC: User Guide to the WMO/GAW World Ozone Data Centre Version 3.0, 2007.

Zhang, L., Jacob, D. J., Boersma, K. F., Jaffe, D. A., Olson, J. R., Bowman, K. W., Worden, J. R., Thompson, A. M., Avery, M. A., Cohen, R. C., Dibb, J. E., Flock, F. M., Fuelberg, H. E., Huey, L. G., McMillan, W. W., Singh, H. B., and Weinheimer, A. J.: Transpacific transport of ozone pollution and the effect of recent Asian emission increases on air quality in North America: an integrated analysis using satellite, aircraft, ozonesonde, and surface observations, Atmos. Chem. Phys., 8, 6117-6136, doi:10.5194/acp-8-6117-2008, 2008.

Ziemke, J. R., Chandra, S., and Bhartia, P. K.: Two new methods for deriving tropospheric column ozone from TOMS measurements: Assimilated UARS MLS/HALOE and convective-cloud differ- 
ential techniques, J. Geophys. Res., 103(D17), 22115-22128, 1998.

Ziemke, J. R., Chandra, S., Duncan, B. N., Froidevaux, L., Bhartia, P. K., Levelt, P. F., and Waters, J. W.: Tropospheric ozone determined from Aura OMI and MLS: Evaluation of measurements and comparison with the Global Modeling Initiative's Chemical Transport Model, J. Geophys. Res., 111, D19303, doi:10.1029/2006JD007089, 2006.
Ziemke, J. R., Chandra, S., Labow, G. J., Bhartia, P. K., Froidevaux, L., and Witte, J. C.: A global climatology of tropospheric and stratospheric ozone derived from Aura OMI and MLS measurements, Atmos. Chem. Phys., 11, 9237-9251, doi:10.5194/acp11-9237-2011, 2011. 